\title{
Skewness, Individual Investor Preference, and the Cross-Section of Stock Returns*
}

\author{
Tse-Chun Lin ${ }^{\mathrm{a}, \dagger}$ \\ Xin Liu ${ }^{b, \ddagger}$ \\ ${ }^{\mathrm{a}}$ Faculty of Business and Economics, The University of Hong Kong \\ ${ }^{\mathrm{b}}$ Faculty of Business and Economics, The University of Hong Kong
}

First Draft: June 18, 2015

This Version: February 21, 2017

\begin{abstract}
We find a robust negative relation between skewness/lotter-like features, proxied by maximum return (MAX) over the last month, and future returns for stocks preferred by individual investors. This negative relation is nonexistent for the rest of stocks. We identify stocks preferred by individual investors through bundling 10 stock characteristics associated with their stock preferences. The negative relation between MAX and future return is produced by the stocks preferred by individuals that account for less than $5 \%$ of the overall market capitalization. Our results are robust to alternative definitions of MAX and lotter-like features such as total, idiosyncratic, and expected skewness.
\end{abstract}

JEL classification: D03, G11, G12, G17

Key words: MAX, lottery-like features, skewness, individual investor preference index, cross-sectional return predictability.

\footnotetext{
* The feedback and advice of Burton Hollifield (the editor) and an anonymous referee is gratefully acknowledged. We appreciate helpful comments from Matthew Billett, Kewei Hou, Fan Yang, Jianfeng Yu, Yu Yuan, and seminar participants at The University of Hong Kong.

${ }^{\dagger}$ Tel.: +852-2857-8503; Fax: +852-2548-1152. E-mail address: tsechunlin@hku.hk.

‡ Tel.: +852-2857-1058; Fax: +852-2548-1152. E-mail address: liuxin12@hku.hk.
} 


\section{Introduction}

Several studies have proposed various models to predict the relation between expected stock return and the return's third moment in the cross-section (Barberis and Huang, 2008; Brunnermeier, Gollier, and Parker, 2007; Brunnermeier and Parker, 2005; Mitton and Vorkink, 2007). Although these studies start from different sets of assumptions, their models imply that skewness (total or idiosyncratic) is negatively priced in the equilibrium because investors who have a skewness preference or who prefer stocks with lottery-like features choose to underdiversify. This negative relation is largely supported by the empirical work of Zhang (2005), Boyer, Mitton, and Vorkink (2010), and Bali, Cakici, and Whitelaw (2011), although those studies’ methodologies and measures of skewness are quite different from one another.

In this paper, we examine whether the negative relation between skewness/lottery-like features and future returns concentrates on the stocks preferred by individual investors. Our idea originates from the studies of Kumar (2009), Kumar, Page, and Spalt (2011), Han and Kumar (2013), and Gao and Lin (2015), who show that individual investors prefer to trade lottery-like or positively-skewed stocks because they treat trading as a fun and exciting gambling activity. ${ }^{1}$ Hence, instead of focusing on methodologies or skewness measurements, our paper studies the role of individual investors' stock preference on the negative relation between skewness/lotterylike features and subsequent returns.

The key innovative element of our empirical exercise is the construction of an individual investor preference index by bundling ten stock characteristics that are related to the concentration of individual investors: 1) institutional ownership (Kumar and Lee, 2006); 2) small trade fraction (Han and Kumar, 2013); 3) price level (Kumar, 2009); 4) idiosyncratic volatility (Kumar, 2009); 5) market capitalization (Barber and Odean, 2000; Gao and Lin, 2015; Gompers

\footnotetext{
${ }^{1}$ Conversely, for institutional investors, lottery-like stock holdings can be viewed as a sign of informed investing (Kumar and Page, 2014) instead of a sign of a skewness preference. Barberis and Huang (2008) argue that their framework is unsuitable for institutional investors. Although some poor-performing fund managers with compensation incentives might exhibit gambling-like behavior (see, for example, Brown, Harlow, and Starksm,1996; Koski and Pontiff, 1999; Chen and Pennacchi, 2009), this framework does not apply to well-performing managers or to managers confronting high employment risks (Kempf, Ruenzi, and Thiele, 2009)
} 
and Metrick, 2001); 6) profitability (Gao and Lin, 2015); 7) book-to-market ratio (Barber and Odean, 2000); 8) market beta (Barber and Odean, 2000); 9) abnormal trading volume (Barber and Odean, 2008); and 10) dividend payments (Graham and Kumar, 2006). To construct the individual investor preference index, we average the rankings of each stock associated with these ten stock characteristics to produce a composite ranking index using a methodology similar to that in Stambaugh, Yu, and Yuan (2015) to rank return anomalies. A stock with a high individual investor preference index is favored by individual investors in the cross-section. Sorting stocks based on this composite ranking allows us not only to capture the multi-dimensional stock characteristics preferred by individual investors but also to examine how individual investor preference is associated with the relation between expected stock return and return skewness.

To capture skewness/lottery-like features, we adopt the maximum daily return over the last month (MAX) proposed by Bali, Cakici, and Whitelaw (2011). We choose the maximum daily return over the last month as our main skewness measure because it presents a clear lottery-like feature that can be linked to individual investors' well-documented tendency to invest in lotterylike stocks (Gao and Lin, 2015; Han and Kumar, 2013; Kumar, 2009; Kumar, Page, and Spalt, 2011). ${ }^{2}$ The maximum daily return over the last month also captures the low probability and extreme return states that drive the results in the model of Barberis and Huang (2008). Specifically, at the end of each month, we double sort stocks independently (using the maximum daily return within a month and our individual investor preference index) into quintile portfolios and then examine the subsequent returns of these portfolios.

We find that the maximum daily return over the last month negatively and significantly predicts the cross-section of stock returns in portfolios that are preferred by individual investors ( $3^{\text {rd }}$ to $5^{\text {th }}$ quintiles of the individual investor preference index). These results are robust to controlling for Fama and French factors (market, small-minus-big, high-minus-low, robust-

\footnotetext{
${ }^{2}$ In addition, Barber and Odean (2008) report that driven by limited attention, individual investors trade stocks with extreme one-day returns. Their study is conducted on a daily horizon, whereas MAX presented in Bali, Cakici, and Whitelaw (2011) is a monthly measure.
} 
minus-weak, conservative-minus-aggressive), and Carhart's momentum factor. The negative return predictability monotonically decreases with our individual investor preference index. The predictability power disappears among the stocks that are less preferred by individual investors $\left(1^{\text {st }}\right.$ to $2^{\text {nd }}$ quintiles of the individual investor preference index). In addition, the firm-level regressions with the interactions of maximum daily return over the last month and the individual investor preference index yield consistent results. These findings are consistent with our argument that the negative relation between skewness/lottery-like features and future returns concentrates on the stocks preferred by individual investors.

To understand what drives the stock return predictability of the maximum daily return over the last month, we apply it to subsamples in which we sequentially exclude stocks with the highest individual investor preference index. The methodology is similar to that in Avramov et al. (2007). The results show that the significant profit from the long-short strategy based on the maximum daily return over the last month is derived from a sample of firms that accounts for less than $5 \%$ of the overall market capitalization. ${ }^{3}$ When we exclude firms that are strongly preferred by individual investors, the long-short strategy payoff from the remaining firms becomes statistically insignificant. These results corroborate that the negative relation between the maximum daily return over the last month and subsequent return is concentrated on stocks preferred by individual investors.

We conduct several robustness checks to further support our findings. First, to verify the link between the maximum daily return over the last month and individual investors, we check the relation between the maximum daily returns and subsequent individual trading behavior. We find that there are more small-sized trades, a proxy for retail trading, for the stocks with higher maximum daily return over the last month, consistent with our argument that individual investors play an important role in the return spread based on the maximum daily return over the last month.

\footnotetext{
${ }^{3}$ Measured by Fama-French-Carhart four-factor model and 5\% significant level. 
Second, our results are robust to other skewness measures such as total and idiosyncratic skewness. We construct total and idiosyncratic skewness on a 6-month horizon (as in Kumar (2009)), a 12-month horizon (as in Bali, Cakici, and Whitelaw, 2011), and a 60-month horizon (as in Boyer, Mitton, and Vorkink, 2010). Moreover, we construct the regression-based expected idiosyncratic skewness proposed by Boyer, Mitton, and Vorkink (2010). We find a consistent return predictability of skewness when we focus on the stocks preferred by individual investors. ${ }^{4}$ Under each specification, skewness negatively predicts subsequent stock returns only among stocks that are highly preferred by individual investors. This predictability power disappears among stocks that are the less preferred by individual investors. On the other hand, univariate sorts based on these skewness measures do not yield significant results. Fama-MacBeth (1973) regressions produce similar results. Consistent with our argument, the relation between skewness and subsequent returns exists only for stocks preferred by individual investors.

Finally, our results are robust when we replace the maximum daily return by the average of the $\mathrm{N}(\mathrm{N}=2,3,4$, and 5$)$ highest daily returns over the last month, similar to the robustness checks in Bali, Cakici, and Whitelaw (2011). The return patterns are very similar to the main results. The negative predictability power of the average of the $\mathrm{N}(\mathrm{N}=2,3,4$, and 5$)$ highest daily returns over the last month is mainly driven by the stocks preferred by individual investors.

One might associate our findings with the limits to arbitrage. However, arbitrage constraints should not explain our results. If it is the limit to arbitrage that drives our findings, the skewness/lottery-like spread has to be an anomaly that is initially induced by market inefficiency and frictions. However, the existing theories that we test argue otherwise. In Mitton and Vorkink (2007), skewness preference is directly incorporated into the utility function, whereas in Brunnermeier and Parker (2005), Brunnermeier, Gollier, and Parker (2007), and Barberis and

\footnotetext{
${ }^{4}$ For example, Bali, Cakici, and Whitelaw (2011) cannot replicate the findings in Zhang (2005) and Boyer, Mitton, and Vorkink (2010). They conjecture that differences in methodology might account for the discrepancy because they examine the return predictability at the firm level, whereas the other studies examine the relation at the portfolio level.
} 
Huang (2008), skewness steps in through the perceived probability. With different modeling tools, skewness in these models is negatively priced as an optimal market equilibrium outcome. Investors are willing to hold positively skewed stocks and bear a low return in exchange for a small probability of a large payoff.

Another alternative interpretation of our evidence is that skewness/lottery-like features, especially the maximum daily return over the last month, might be proxies for short-term reversal. When sorting stocks by maximum daily return over the last month, high maximum return stocks mechanically show a high return in the previous month. We address this concern in two ways. At the portfolio level, we include a short-term reversal factor when estimating the risk-adjusted alphas of high-minus-low strategies. The conditional pattern still exists after controlling for this additional factor. ${ }^{5}$ At the firm level, short-term reversal is controlled in the cross-sectional regressions. Although short-term reversal has strong predictability on stock returns, it does not subsume the effect of skewness/lottery-like features.

As individual investors prefer stocks with positive idiosyncratic skewness (Kumar, 2009), there is a concern that sorting stocks based on the individual preference index might be the same as sorting on the lottery-like measures. However, we argue that the return predictability of lotterylike features and the individual investor preference are related but not the same in the following aspects. First, we do not find robust return predictability for the individual investor preference index alone. Second, the theoretical foundation of the return predictability of skewness/lotterylike features is linked to individual investors. However, the return predictability of some stock characteristics preferred by individual investors is not originated from individual investors preference or behavior. Third, maximum daily return and the individual investor preference index are only mildly correlated (approximately 30\%) and thus still capture a substantial amount of different information. Fourth, although the existing literature shows that the average individual

\footnotetext{
${ }^{5}$ These results are reported in the Internet Appendix A1.
} 
investors' portfolios underperform, the crucial point here is that it is the individual investors who lose money over time; it is not that the stocks they prefer underperform in the cross-section.

This paper contributes to the literature in several ways. First, our results shed light on the theoretical studies of the relation between expected stock returns and the third moment by showing that return predictability is mainly driven by stocks preferred by individual investors. Our results are consistent with the individual trading literature that finds that some individual investors prefer lottery-like stocks for the small probability of a large payoff. Second, our paper adds to the empirical literature on testing theoretical models. One of the primary challenges in this line of research is that skewness is difficult to measure because it is not stable over time, it is strongly influenced by outliers, and it is subject to seemingly arbitrary trailing windows. ${ }^{6}$ Our findings indicate that considering the preference of individual investors as an additional dimension yields robust and consistent results across methodologies and measurements. When conditioning on individual investor preference, all measures of skewness/lottery-like features yield consistent results at both the portfolio and firm levels. Finally, we add to the individual investor trading literature by proposing a composite index to capture individual investors' preference. This individual investor preference index enables us not only to directly compare the relative tendency of individual investors' concentration in the cross-section but also to test the influence of individual investors in the stock returns dynamics.

The remainder of this paper is structured as follows. Section 2 describes our data and individual investor preference index construction. Section 3 provides our main analysis on the maximum daily return over the last month and the individual investor preference index. In Section 4.1, we conduct a subsample analysis to understand the link between the maximum daily return spreads and individual investor preference index; in Section 4.2, we check whether individual investors trade heavily on stocks with a high maximum daily return over the last

\footnotetext{
${ }^{6}$ See, for example, Harvey and Siddique (1999), Chen, Hong, and Stein (2001), Boyer, Mitton, and Vorkink (2010), and Gao and Lin (2015).
} 
month. We provide robustness checks across different skewness measures and different specifications of maximum daily return over the last month in Section 4.3 and Section 4.4. Section 4.5 discusses the potential circularity concern. Section 5 concludes.

\section{Data and Individual Investor Preference Index}

\subsection{Data}

We use data from the Center for Research in Security Prices (CRSP) data, which contains common share stocks listed on the New York Stock Exchange (NYSE), the American Stock Exchange (Amex), and the NASDAQ. We use daily stock returns to calculate the maximum daily return (MAX) over the last month for each stock in each month, along with variables including market beta, idiosyncratic volatility, and co-skewness. We use daily volume to calculate a measure for illiquidity (ILLIQ) based on Amihud (2002). Daily volume and shares outstanding are used to calculate average turnover ratio and abnormal trading volume. We use monthly returns to calculate proxies for momentum and short-term reversal. Share prices and shares outstanding are used to calculate market capitalization. Net stock issuance is calculated from split-adjusted shares outstanding. We use distribution information provided by CRSP to identify whether a stock has paid a dividend in the previous year.

We use quarterly Compustat information to obtain equity book values, profitability measures (EPS, net income, ROE, ROA, gross profit), asset growth rate, and accruals. Institutional holdings are obtained from Thomson Reuters $13 \mathrm{~F}$ to calculate the percentage of institutional ownership. All accounting data and institutional holdings are lagged for two months to ensure their availability to the market and then held constant for three months until new information arrives.

We construct the small trade fraction using the Trade and Quote (TAQ) database, which contains intraday, tick-by-tick trade, and quote data for all activity in the U.S. National Market 
System. We identify each trade in TAQ as buyer- or seller-initiated following the procedure outlined in Lee and Ready (1991). All of the variables are defined in detail in the Appendix.

\subsection{Capturing Individual Investor Preference}

One way to measure which types of stocks individual investors prefer is to examine their holdings. Because we do not have account-level information across the stock universe, we can only estimate it in the aggregate level through quarterly institutional ownership data. The higher the institutional ownership of a stock, the lower the individual ownership. If we assume that individual investors' trading volume is positively related to their holdings, then we anticipate that the negative relation between stock return and skewness either should be stronger or should only exist in stocks with lower institutional ownership. Thomson Reuters began to provide information on institutional ownership in 1980; however, we realize the shortcoming of the institutional ownership measure. For instance, small institutions do not have to file 13F, which we rely upon to calculate institutional ownership. ${ }^{7}$ Therefore, the institutional ownership measure constructed from $13 \mathrm{~F}$ underestimates the real level of institutional ownership and thus overestimates individual holding and trading.

Unlike the ownership measure, a more direct way of identifying the stocks preferred by individual investors is to examine their trading. A large literature stream uses small trades, which are identified as trades with a dollar volume of no more than USD 5,000, as a proxy for retail trades (e.g., Barber, Odean, and Zhu, 2009; Battalio and Mendenhall, 2005; Brandt et al., 2010; Campbell, Ramadorai, and Schwartz, 2009; Derrien, 2005; Han and Kumar, 2013; Hvidkjaer, 2006; Hvidkjaer, 2008; Lee and Radhakrishna, 2000; Lou, 2014; Malmendier and Shanthikumar, 2007; Malmendier and Shanthikumar, 2014; Ofek and Richardson, 2003; Yuan, 2015)

\footnotetext{
${ }^{7}$ Institutional investment managers who exercise investment discretion over $\$ 100$ million or more in Section 13(F) securities must file Form 13F. See Section 13(F)(1) of the Securities Exchange Act. 
We construct a small trade fraction on a monthly horizon as the ratio of small trade volume over total volume. To account for changes in purchasing power over time, trade size is based on 1991 real dollars and adjusted using the Consumer Price Index. We require a minimum of 50 trades in a month to construct this ratio. A higher small trade fraction for a stock indicates that individual investors trade more on that stock. However, identifying investors through trade size is only shown to be effective before early 2000 because of the widespread introduction of decimalization and the growing use of computerized trading algorithms. Meanwhile, the TAQ database is not available before 1993. Therefore, we construct the small trade fraction beginning in 1993 and ending in July 2000 because decimalization is introduced in August 2000.

In addition to institutional ownership and small trade fraction, we consider low price-level and high idiosyncratic volatility as characteristics preferred by individual investors, as outlined in Kumar (2009). We take the absolute value of month-end price from CRSP as the price level. Idiosyncratic volatility is constructed as the standard deviation of the residual obtained by fitting Fama and French (1993) and Carhart (1997) four-factor model to the daily stock returns timeseries over the previous six months.

Some studies also show that individual investors prefer stocks with low market capitalization (Barber and Odean, 2000; Gao and Lin, 2015; Gompers and Metrick, 2001). Additionally, Gao and Lin (2015) argue that individual investors prefer stocks with low profitability, as proxied by earnings per share. Thus, we also consider low profitability as a stock characteristic preferred by individual investors. To obtain a robust proxy for profitability and to mitigate the concern about data mining on a particular measure, we adopt five profitability measures (earnings per share, return on equity, return on assets, net income over total assets, and gross profit over total assets) and bundle them into a composite profitability rank. Specifically, we rank all stocks in our sample by each of the five profitability measures. The higher a stock's profitability, the higher 
it's rank. A stock's profitability rank is the arithmetic average of its ranking percentile across each of the five profitability measures.

Moreover, Barber and Odean (2000) argue that individual investors prefer stocks with a high market beta and a high book-to-market ratio. We construct monthly market beta using daily returns following Scholes (1977) and Dimson (1979) to take into account nonsynchronous trading. The book value of equity is computed at the quarterly level.

Barber and Odean (2008) shows that individual investors are net buyers of stocks with abnormal trading volumes due to attention grabbing. Since their study is performed on the daily level, we construct a similar abnormal trading volume measure at the monthly level, i.e., the maximum daily trading volume in month $t$ divided by the average daily trading volume from month $\mathrm{t}-12$ to month $\mathrm{t}-1$.

The final stock characteristic that we consider is dividend payment. Graham and Kumar (2006) show that in general, individual investors prefer non-dividend-paying stocks. Thus, at the end of each month, any stock that makes a dividend payment in the previous year is classified as a dividend-paying stock.

\subsection{Individual Investor Preference Index}

Motivated by the existing literature, we consider the following ten stock characteristics: 1) institutional ownership (Kumar and Lee, 2006); 2) small trade fraction (Han and Kumar, 2013); 3) price level (Kumar, 2009); 4) idiosyncratic volatility (Kumar, 2009); 5) market capitalization (Barber and Odean, 2000; Gao and Lin, 2015; Gompers and Metrick, 2001); 6) profitability (Gao and Lin, 2015); 7) book-to-market ratio (Barber and Odean, 2000); 8) market beta (Barber and Odean, 2000); 9) abnormal trading volume (Barber and Odean, 2008); and 10) dividend payments (Graham and Kumar, 2006). We combine these stock characteristics into a monthly composite index that captures individual investors' concentration in the cross-section of stocks. 
Our method of constructing the composite individual investor preference index is consistent with the spirit of the anomalies index in Stambaugh, Yu, and Yuan (2015). ${ }^{8}$ More specifically, for each stock characteristic, we assign a percentile rank to each stock that reflects the sorting on that given characteristic, where a higher rank is assigned to the value of the characteristic that is preferred by individual investors (i.e., lower institutional ownership, higher small trade fraction, lower price level, higher idiosyncratic volatility, lower market capitalization, lower profitability rank, higher book-to-market ratio, high market beta, high abnormal trading volume, and nondividend payment). All of the accounting and ownership variables are lagged for two months to ensure market availability and are kept constant until new information arrives. A stock's composite rank is then the arithmetic average of its ranking percentile for each of the ten characteristics. ${ }^{9}$

We refer to the stocks with the highest composite ranking as individual investors' preferred stocks and those with the lowest ranking as individual investors' most disliked stocks. Although each stock characteristic itself is a potential preference proxy, our objective in combining them is to produce a single measure that diversifies away some noise in each characteristic and thereby increases comprehensiveness when capturing individual investor preferences. ${ }^{10}$ For the main analysis, we include stocks for which at least six of these characteristics can be computed. We drop this restriction in the robustness checks. The index starts in January 1976 to ensure there are enough stocks in the corner portfolios.

We acknowledge that we are unable to precisely determine individual trading through these ten characteristics. However, because our goal is to show that the negative relation between expected stock return and skewness is largely driven by stocks preferred by individual investors, a reasonable composite measure that helps us to rank stocks accordingly would serve our purpose.

\footnotetext{
${ }^{8}$ We thank an anonymous referee for this suggestion.

${ }^{9}$ Because dividend payment is a dummy variable, we assign the highest-ranking percentile to non-dividend paying stocks and the lowest ranking percentile to dividend-paying stocks.

${ }^{10}$ This individual investor preference index is constructed in a cross-sectional fashion, so the index reflects only the relative tendency of individual investors trading in a given month.
} 


\subsection{Summary Statistics}

Table 1 reports the time-series average of each month's average values of the stock characteristics for the quintile portfolios sorted by MAX.

\section{[TABLE 1 HERE]}

These portfolios exhibit noteworthy patterns. As we move from the low MAX quintile to the high MAX quintile, the average of MAX increases from $2.03 \%$ to $18.38 \%$. These values are in line with the numbers reported in Bali, Cakici, and Whitelaw (2011) and Bali et al. (2014).

MAX and the ten stock characteristics are clearly correlated. On average, institutions hold fewer high-MAX stocks. Average institutional ownership drops from $40 \%$ to $22 \%$ as MAX increases from the lowest quintile to the highest quintile. This is not surprising given that institutional investors tend to invest in large-cap stocks (Gompers and Metrick, 2001). Second, high-MAX stocks tend to be traded by individual investors, as indicated by the small trade fraction. For stocks in the highest MAX quintile, approximately 36\% of the total monthly trading volume comes from small trades, i.e., trades with a dollar volume lower than USD 5,000. This ratio represents only approximately $6 \%$ of stocks in the lowest MAX quintile.

Moreover, stocks with higher MAX are generally associated with lower profitability, lower market capitalization, lower price level, higher idiosyncratic volatility, higher book-to-market ratio, higher market beta, higher abnormal trading volume, and lower likelihood to have paid a dividend in the previous year. Unsurprisingly, these patterns are also reflected in the composite individual investor preference index. Stocks in the highest MAX quintile receive an average ranking of 74, whereas stocks in the lowest MAX quintile only receive an average ranking of 25.

[TABLE 2 HERE] 
Table 2 reports the correlation matrix of all the variables used in the preference index, as well as MAX. This matrix shows that the composite ranking index is mainly correlated with institutional ownership (-65\%), small trade fraction (77\%), profitability $(-61 \%)$, size $(-76 \%)$, idiosyncratic volatility (62\%), and dividend payment (-64\%). In addition, our measure of proxy for lottery-like feature MAX is mildly positively correlated with the preference index (33\%). Therefore, we conduct independent double sorts to make sure that the benchmarks for high (low) MAX and high (low) preference index are the same across all portfolios.

\section{Main Results}

\subsection{Bivariate Portfolio-level Analysis}

In this section, we test the negative relation between MAX and future stock returns conditioning on the individual investor preference index. At the end of each month, we construct MAX following Bali, Cakici, and Whitelaw (2011) and an individual investor preference index as outlined in the previous section. We first conduct a univariate sort on MAX to check how MAX predicts the cross-section of stock returns in the whole sample. We then conduct independent double sorts at the end of each month by MAX and the composite index, examining the subsequent portfolio returns to see how the univariate results are decomposed with respect to the preference index. Table 3 reports these results.

\section{[TABLE 3 HERE]}

We first report the value-weighted average returns from quintile portfolios sorted on MAX (columns 1 to 5) and then calculate the return difference between the high-MAX portfolio and the low-MAX portfolio (column 6). The raw return difference are further adjusted by the Fama and French (1993) three-factor model (column 7), the Fama-French-Carhart four-factor model (column 8), the Fama and French (2015) five-factor model (column 9), and a six-factor model using the five Fama and French (2015) factors and the Carhart (1997) momentum factor (column 10). Newey-West adjusted test statistics are reported in parentheses. Following the univariate sort, 
we report the value-weighted average returns from all $25(5 \times 5)$ bivariate portfolios (columns 1 to 5) and the high-minus-low spreads for each of the individual investor preference index quintiles (columns 6-10)

Table 3 first confirms that MAX does negatively predict the cross-section of stock returns. The raw return difference between the highest MAX quintile portfolio and the lowest MAX quintile portfolio is $-0.53 \%$ and significant at $10 \%(\mathrm{t}$-stat $=-1.74)$. This spread becomes stronger under the Fama-French three-factor model $($ alpha $=-0.96$, t-stat $=-4.37)$ and the Fama-French-Carhart four-factor model (alpha $=-0.73$, t-stat $=-3.24)$. However, part of the predictability power is taken away under the new Fama-French five-factor model with investment and profit factors $($ alpha $=-0.34, \mathrm{t}$-stat $=-1.97)$. The spread becomes insignificant after controlling for the FamaFrench five factors and Carhart's momentum factor.

We then decompose this return pattern by the individual preference index quintiles. The double sorting shows that the negative return predictability of MAX is monotonically increasing with the individual preference index. The raw return for the high-minus-low MAX spread in the lowest individual preference index quintile is close to zero with a t-stat of -0.31 . Conversely, the highminus-low MAX spread in the highest individual preference index is $-1.50 \%$ with a $t$-stat of -4.21. This spread is three times larger than the unconditional raw spread, with a t-statistic also three times larger. In addition, this monotonicity pattern is robust to all of the factor models. For example, in column 10, the six-factor adjusted return for the high-minus-low MAX spread in the lowest individual preference index quintile is $0.34 \%$ (t-statistic $=1.21)$ and insignificant, whereas the six-factor risk-adjusted return for the high-minus-low MAX spread in the highest individual preference index is -1.29 (t-statistic $=-3.64$ ). This alpha is approximately five times larger than the statistically insignificant unconditional six-factor alpha, which highlights the economic relevance of our individual investor preference index. 
We report the double sorting results between MAX and each of the ingredients from the preference index in the Internet Appendix A2. Most of the double sorts exhibit similar patterns as those reported here. Collectively, these tests document the conditional negative return predictability of MAX on stocks preferred by individual investors. ${ }^{11}$ The evidence in this subsection is consistent with our argument that the negative relation between skewness/lotterylike features and future returns concentrates on the stocks preferred by individual investors. ${ }^{12}$

\subsection{Fama-MacBeth Regressions}

The primary advantage of double-sort portfolio analysis in the previous subsection is that it offers a simple picture of how average returns vary across the spectrum of predictive variables such that we do not impose a functional form on the relations. However, we cannot control for some known features that have asset-pricing implications in the cross-section. Therefore, in this subsection, we conduct Fama and MacBeth (1973) regressions to examine whether the results from the portfolio-level analysis continue to hold at the firm level.

To be consistent with the previous portfolio-level analysis, we first divide our sample into five groups based on the individual investor preference index. Each group is then assigned a dummy variable that equals one if a stock is in that group. More specifically, I (port=Low) is a dummy variable that equals one if a stock is in the lowest index quintile and otherwise zero; I (port=High) is a dummy variable that equals one if a stock is in the highest index quintile and otherwise zero; I (port=2), I (port=3) and I (port=4) are defined accordingly. When we test each of the ten stock characteristics preferred by individual investors separately (reported in Internet Appendix A3), these five dummies are defined in a similar fashion. In doing so, we divide a single regression coefficient that appears in Bali, Cakici, and Whitelaw (2011) into five; thus, we can observe how

\footnotetext{
${ }^{11}$ Our results are not driven by small stocks given that we find similar results after excluding all stocks with prices below $\$ 5$ per share.

${ }^{12}$ The result is also in line with An et al. (2015), who find that the underperformance of lottery-like stocks are reference-dependent because individual investors might exhibit a stronger pattern of reference-dependence in their decision-making process.
} 
the predictability of MAX varies when it is conditioned on the spectrum of stock characteristics preferred by individual investors.

We present the time-series averages of the slope coefficients from the following monthly crosssectional regressions:

$$
\begin{aligned}
R_{\mathrm{i}, \mathrm{t}+1}= & \lambda_{0, \mathrm{t}}+\sum_{\mathrm{j}} \lambda_{\mathrm{j}, \mathrm{t}} M A X_{\mathrm{i}, \mathrm{t}} \times I(\text { port }=\mathrm{j})+\lambda_{6, \mathrm{t}} I N D E X_{\mathrm{i}, \mathrm{t}}+\lambda_{7, \mathrm{t}} \operatorname{BETA}_{\mathrm{i}, \mathrm{t}}+\lambda_{8, \mathrm{t}} \operatorname{SIZE}_{\mathrm{i}, \mathrm{t}}+\lambda_{9, \mathrm{t}} B_{E M E_{\mathrm{i}, \mathrm{t}}} \\
& +\lambda_{10, \mathrm{t}} \operatorname{MOM}_{\mathrm{i}, \mathrm{t}}+\lambda_{11, \mathrm{t}} \operatorname{STREV} V_{\mathrm{i}, \mathrm{t}}+\lambda_{12, \mathrm{t}} I L L I Q_{\mathrm{i}, \mathrm{t}}+\lambda_{13, \mathrm{t}} \operatorname{IVOL}_{\mathrm{i}, \mathrm{t}}+\lambda_{14, \mathrm{t}} \operatorname{COSKEW}_{\mathrm{i}, \mathrm{t}}+\lambda_{15, \mathrm{t}} N S_{\mathrm{i}, \mathrm{t}} \\
& +\lambda_{16, \mathrm{t}} \operatorname{ASSETG}_{\mathrm{i}, \mathrm{t}}+\lambda_{17, \mathrm{t}} A C C R U A L S_{\mathrm{i}, \mathrm{t}}+\lambda_{18, \mathrm{t}} \operatorname{TURNOVER}_{\mathrm{i}, \mathrm{t}}+\varepsilon_{\mathrm{i}, \mathrm{t}}
\end{aligned}
$$

where $R_{\mathrm{i}, \mathrm{t}+1}$ is the realized return on stock $i$ in month $t+1, \mathrm{MAX}_{\mathrm{i}, \mathrm{t}}$ is the maximum daily return from the previous month for stock $i, I($ port $=\mathrm{j})(\mathrm{j}=1,2,3,4$, and 5$)$ are the five dummies according to the preference index quintiles, and INDEX $X_{\mathrm{i}, \mathrm{t}}$ is the individual preference index value for stock $i$. Control variables include: 1) market beta (BETA), constructed following Scholes and Williams (1977) to take into account nonsynchronous trading; 2) size (SIZE), the log value of total market capitalization; 3) book-to-market ratio (BEME), the book value of equity over market value of equity from the most recent quarter; 4) momentum (MOM), the cumulative return from month $t$ 12 to month $t-1$; 5) short-term reversal (STREV), stock return from the previous month; 6) illiquidity (ILLIQ), the average ratio of the absolute daily stock returns to its dollar trading volume, as outlined by Amihud (2002); 7) idiosyncratic volatility (IVOL), the standard error of the residual obtained by fitting a four-factor model to the previous six months' daily stock returns; 8) coskewness with the market (COSKEW), constructed by daily returns from the past 12 months; 9) net stock issuance (NS), the change in the natural log of split-adjusted shares outstanding; 10) asset growth (ASSETG), the quarterly growth rate of total assets; 11) accruals (ACCRUALS), constructed following Sloan (1996); and 12) turnover ratio (TURNOVER), average daily turnover ratio within each month. Detailed definitions for all of the control variables can be found in the Appendix. The predictive cross-sectional regressions are performed with the one-month lagged values of the right-hand-side variables. Variables are winsorized at the $1 \%$ and $99 \%$ 
percentiles to eliminate the potential influence of outliers. Table 4 reports the time-series average of the slope coefficients for our sample over the 468 months from January 1976 to December 2014. The Newey-West adjusted t-statistics are provided in parentheses.

\section{[TABLE 4 HERE]}

Table 4 shows a clear pattern in which the negative predictability of MAX appears only in stocks with a high preference index. In column 1, we find that the average regression coefficient on MAX in the lowest preference quintile is not significant. On the other hand, for the interaction with the highest preference quintile, the average regression coefficient is -0.095 with a t-statistic of -11.72 . As shown in Table 1 , the spread in the average MAX between quintile 5 and quintile 1 is approximately $16.32 \%$. Multiplying this spread by the average coefficient yields an estimate of the monthly risk premium as approximately $1.55 \%$ per month. This result is both economically and statistically significant. In column 4, we include all the interaction terms between MAX and the preference index quintile and still find that the average coefficient of MAX on the highest preference quintile is unchanged (coefficient $=-0.047$, t-stat $=-4.52$ ). As the preference index drops from the top quintile to the bottom quintile, the negative relation of MAX and subsequent stock returns gradually disappears.

The Fama-MacBeth regression coefficients provided in Table 4 are in line with the portfoliolevel analysis provided in Table 3. The negative return predictability of MAX in the cross-section only exists for stocks preferred by individual investors. These results are consistent with the portfolio sorting analysis in the previous subsection.

\section{Robustness Check}

In this section, we conduct additional tests to establish the robustness of our main results. In Section 4.1, we decompose returns from the MAX strategy into subsamples to understand the link between the MAX spread and the individual investor preference index. In Section 4.2, we examine subsequent trading volume by trade size to reveal the link between MAX and individual 
investor trading. Sections 4.3 and 4.4 provide results based on seven skewness measures in the literature and alternative constructions of MAX, respectively. In the robustness checks, we relax the restriction that at least six of stock characteristics should be available to get the individual investor preference index. $^{13}$

\subsection{Subsample Analysis}

In the previous section, we showed that the relation between MAX and stock returns in both portfolio- and firm-level analyses is concentrated on stocks preferred by individual investors. We now implement the univariate MAX strategy in Bali, Cakici, and Whitelaw (2011) with subsamples containing a decreasing amount of stocks preferred by individual investors. More specifically, we begin with the entire sample and then sequentially exclude stocks with the highest composite individual investor preference index. This analysis helps us identify the subsample of firms that drive MAX spreads. This analysis is based on the methodology of Avramov et al. (2007), who examine the link between momentum profits and credit rating.

\section{[TABLE 5 HERE]}

We divide the sample into twenty groups based on our composite index. It is worth noting that stocks with a high individual preference index have low market capitalizations. Table 5 reports the average payoffs from the MAX strategy in each subsample as we sequentially drop stocks with the highest composite preference index. Portfolios are rebalanced every month, and we report the time-series average of four-factor, five-factor, and six-factor adjusted MAX spreads, the time-series average of the percentage of market capitalization, and the time series average of the percentage of the total number of firms included in each subsample. Newey-West t-statistics for the MAX profits are provided in parentheses. As shown in Table 5, stocks in the top 50\% of the individual preference index represent only $4.43 \%$ of the total market capitalization. As we

\footnotetext{
${ }^{13}$ Results are very similar if we still use this restriction.
} 
sequentially drop stocks within the highest index group, the MAX profits drop monotonically. The four-factor adjusted payoffs to MAX strategy become insignificant at 5\% level when the top $55 \%$ of the stocks in the preference index are excluded from the sample. $45 \%$ of the remaining stocks account for more than $94 \%$ of the market capitalization of the entire sample. The fivefactor adjusted payoffs to MAX strategy become insignificant when the top $30 \%$ of stocks in the individual investor preference index are excluded from the sample. The $70 \%$ of firms that remain in the sample account for approximately $99 \%$ of the market capitalization of the entire sample.

We find that the six-factor alpha from the univariate sorting on MAX is insignificant in the whole sample. This is consistent with the univariate sorting result presented in Table 3 (the first row of the last column). However, Table 3 also shows that when we double sort stocks based on MAX and the individual preference index, we can still find significantly negative six-factor alphas among stocks highly preferred by individual investors. These results corroborate our main finding that considering individual investors’ preference as an additional dimension is crucial to understand the MAX effect, and the negative relation between MAX and subsequent stock returns are mostly concentrated among stocks preferred by individual investors.

Alternatively, we can sequentially drop firms in the lowest index group. We find that MAX profits increase monotonically as stocks less preferred by individual investors are excluded. This result (reported in Internet Appendix A4) is in line with the previous finding that the MAX phenomenon is primarily driven by stocks that are preferred by individual investors.

\subsection{MAX and Subsequent Trading}

Up to this point, we have shown that the MAX spread is primarily concentrated on the stocks preferred by individual investors. To better support our argument, we examine the trading record for each stock to determine whether individual investors indeed trade more stocks with higher MAX in the previous month. To do so, we follow the large stream of literature that uses trade size 
as a proxy to differentiate trades from individual investors and institutional ones, as outlined by Lee and Radhakrishna (2000). We partition trades into five bins based on trade size (T): a) $\mathrm{T}<=\$ 5,000 \quad$ (small $\quad$ trades); b) $\quad \$ 5,000<\mathrm{T}<=\$ 10,000 ; \quad$ c) $\quad \$ 10,000<\mathrm{T}<=\$ 20,000 ; \quad$ d) $\$ 20,000<\mathrm{T}<=\$ 50,000 ;$ and e) $\$ 50,000<\mathrm{T}$ (large trades). Trades of less than $\$ 5,000$ (small trades) are used as a proxy for individual investor trades, whereas trades of more than $\$ 50,000$ (large trades) are used as a proxy for institutional trades. This analysis enables us to distinguish individual trades from institutional trades. To account for changes in purchasing power over time, trade size bins are based on 1991 real dollars and are adjusted by the Consumer Price Index. For each stock, we first calculate the ratio of trading volume from each trade bin and then match MAX from the previous month to these ratios. Based on MAX, the sample is sorted into quintile portfolios. In Panel A of Table 6, we report the time-series average trading percentage across each trade bin for stocks in MAX quintile portfolios. Because of the availability of TAQ data, the introduction of decimalization, and the growing use of computerized trading algorithms, this exercise uses data from 1993 to 2000.

\section{[TABLE 6 HERE]}

The percentage of small trades increases with MAX, suggesting that individual investors prefer to trade stocks that just experienced a high MAX in the previous month. For stocks experiencing high MAX (top quintile), approximately $36 \%$ of the subsequent monthly trading volume is contributed by individual investors (small trades), whereas only $16 \%$ is contributed by institutional investors (large trades). For stocks that experienced low MAX (bottom quintile), more than half of the subsequent monthly trading volume is contributed by institutional investors, whereas only $7 \%$ of the volume is contributed by individual investors. Moreover, the average percentage of small trades grows monotonically across MAX quintiles, whereas the pattern is reversed for large trades. This evidence suggest that individual investors prefer to trade stocks with high MAX from the previous month. 
We then decompose trades into buyer-initiated and seller-initiated ones, as outlined in Lee and Ready (1991). Specifically, trades are identified as buyer-initiated through a two-step approach: first a quote test and then a tick test. The quote rule identifies trades as buyer-initiated if the trade price is above the midpoint of the most recent bid-ask quote. The tick rule identifies a trade as buyer-initiated if the trade price is above the last executed trade price. This two-way identification procedure is also adopted in Barber, Odean, Zhu (2009). We compute the ratio of buy-volume across five trade-size bins for each stock. We repeat the analysis in Panel A of Table 6 for these buy-volume ratios.

Panel B of Table 6 shows that of all the buyer-initiated trades for stocks in the top MAX quintile, approximately 36\% are contributed by individual investors, whereas only 15\% are contributed by institutions. Conversely, of all the buyer-initiated trades for stocks in the bottom MAX quintile, only approximately 7\% are contributed by individual investors, whereas 54\% are contributed by institutions. Overall, the pattern in Panel B is very similar to that in Panel A.

These analyses complement our previous tests by showing that individual investors are indeed the major traders of stocks that have experienced a high maximum return in the previous month.

\subsection{Skewness Measures}

In the previous analyses, we adopt the maximum daily return from the previous month (MAX) proposed by Bali, Cakici, and Whitelaw (2011) to capture lottery-like/positive-skewed features. In this subsection, we replace MAX by seven skewness measures to check whether our main results continue to hold. We expect to find that the negative relation between stock return and lottery-like features remains concentrated on stocks preferred by individual investors, while using these alternative measures to capture the lottery-like features.

The existing literature uses various time horizons to construct skewness proxies. Kumar (2009) computes skewness using daily returns from the previous six months. Bali, Cakici, and Whitelaw 
(2011) construct skewness using daily returns from the past twelve months. Boyer, Mitton, and Vorkink (2010) apply a 60-month time window. We try all of these time horizons to compute skewness in this subsection. At the end of each month $t$, we compute both total and idiosyncratic skewness (TSKEW/ISKEW) measures using daily returns from the previous 6/12/60 months. We also follow Boyer, Mitton, and Vorkink (2010) and construct expected idiosyncratic skewness at the 60-month horizon (EISKEW).

Various methods have been adopted to construct idiosyncratic skewness. In Kumar (2009) and Bali, Cakici, and Whitelaw (2011), idiosyncratic skewness measures are constructed following Harvey and Siddique (2000). Specifically, idiosyncratic skewness is a scaled measure of the third moment of the residual obtained by fitting a two-factor model to the daily stock returns time series, where the two factors are the excess market returns and the squared excess market returns. In Boyer, Mitton, and Vorkink (2010), idiosyncratic skewness is defined as the third moment of the residual obtained by fitting the Fama and French (1993) three-factor model to the daily stock returns time series. We strictly follow these papers when constructing skewness measures for different time windows.

We report the correlation matrix of all these skewness measures along with MAX and the individual investor preference index in Table 2. From Table 2, we can observe that all these measures are significantly correlated with one another. MAX is $26 \%$ correlated with TSKEW(6m), 24\% correlated with ISKEW(6m), 23\% correlated with TSKEW(12m), 22\% correlated with ISKEW(12m), 21\% correlated with TSKEW(60m), 20\% correlated with ISKEW(60m) and 38\% correlated with EISKEW. ${ }^{14}$ The general trend from this correlation matrix is that the correlation with MAX drops as the difference in the observation window

\footnotetext{
${ }^{14} \mathrm{MAX}$ and skewness measures both capture one dimension of return distribution, i.e., a small probability of a large payoff. Therefore, they can serve as proxies for lottery-like features. The major difference between these proxies is the estimation horizon. MAX, by definition, is relatively short-term as it is the maximum daily return in the previous month. It thus captures the potential maximum daily return an investor could have received in the previous month. The skewness measures we adopt, in contrast, are constructed using much longer time-series data (past 6-month, 12month, or 60-month returns). Hence, these skewness measures might contain different information regarding the return distribution.
} 
widens. All these skewness measures have lower correlation coefficients with the individual investor preference index compared to MAX, except for the expected idiosyncratic skewness, which incorporates some of the index ingredients.

At the end of each month, we first sort on each of the skewness measures for the whole sample, and then, we double sort by skewness and by the individual investor preference index independently. Next, we compute subsequent value-weighted portfolio returns. The results are provided in Table 7 in a similar fashion as those in Table 3.

\section{[TABLE 7 HERE]}

Table 7 shows that regardless of which skewness measure is adopted, sorting on skewness alone cannot produce robust results. Skewness negatively predicts the cross-section of returns only among stocks preferred by individual investors. The predictability power increases with the composite preference index. Panel A of Table 7 reports the sorting results based on total skewness constructed on a 6-month horizon. When sorting by TSKEW alone, the high-minus-low spread is close to zero and not statistically significant. However, the high-minus-low spread on TSKEW among stocks in the highest index quintile is approximately $-0.84 \%(\mathrm{t}$-statistic $=-2.99)$, whereas the high-minus-low spread on TSKEW among the lowest index quintile is $0.04 \%$ (tstatistic $=0.37$ ). Panel $\mathrm{B}$ of Table 7 , which shows idiosyncratic skewness constructed on a 6month horizon, displays similar patterns. Univariate sorting on ISKEW yields negative but insignificant results, but the high-minus-low spread on ISKEW is negatively significant only among stocks in the highest index quintile, with an average spread of $-0.84 \%$ and a Newey-West adjusted t-statistic of -3.10 .

In Panels $\mathrm{C}$ and $\mathrm{D}$, we report the results on the return predictability of total and idiosyncratic skewness, respectively, constructed on a 12-month horizon. The high-minus-low spread of TSKEW is negative and significant only among stocks in the highest preference index quintile, 
with average return of $-0.95 \%$ ( $\mathrm{t}$-statistic $=-3.38)$, whereas the high-minus-low spread of ISKEW is negative and significant only among stocks in the highest preference index quintile, with an average return of $-1.01 \%$ (t-statistic $=-3.31)$. No robust patterns can be found for the other index quintiles. Although the univariate sort on either TSKEW or ISKEW cannot produce statistically significant return spread, our results indicate that the negative correlation between skewness and return exists for stocks preferred by individual investors.

In Panels E, F, and G, we test total skewness, idiosyncratic skewness, and expected idiosyncratic skewness, respectively, on a 60-month horizon. These three panels produce results that are consistent with the previous ones. The high-minus-low spread on TSKEW among stocks in the highest index quintile is $-0.87 \%$ (t-statistic $=-2.44$ ) in Panel $\mathrm{E}$, the high-minus-low spread on ISKEW among stocks in the highest index quintile is $-0.62 \%$ (t-statistic $=-1.80$ ) in Panel F, and the high-minus-low spread on EISKEW among stocks in the highest index quintile is $-0.63 \%$ (t-statistic $=-1.91)$ in Panel G. No robust results are found in the other quintiles.

In addition, the return patterns presented in Table 7 are robust after controlling for the five Fama and French factors (market, SMB, HML, RMW, and CMA) and Carhart's momentum factor, as shown in the final four columns in each panel. These results show that our findings are not driven by these known factors.

In Table 8, we perform Fama-MacBeth regressions to check whether the results from Table 7 hold at the firm level. Similar to the analysis reported in Table 4, we first divide our sample into five groups according to the composite individual investor preference index and then assign dummy variables for each group. We present the time-series averages of the slope coefficients from the regressions of stock returns on the five interaction terms (SKEW $\times$ dummy), along with the control variables. Newey-West t-statistics are provided in parentheses.

\section{[TABLE 8 HERE]}


Each column in Table 8 reports results for each of the corresponding seven skewness measures. All of these columns consistently show that the average slope coefficients for skewness are negative and significant only among stocks that are preferred by individual investors.

The evidence shown in Tables 7 and 8 supports our argument that focusing on stock characteristics preferred by individual investors is the key to testing the theories of the relation between the third moment and the cross-section of expected stock returns. We find our main results robust across total and idiosyncratic skewness proxies. That is, total and idiosyncratic skewness negatively predict the cross-section of stock returns among stocks preferred by individual investors.

\subsection{Alternative Construction of MAX}

Bali, Cakici, and Whitelaw (2011) propose the monthly maximum daily return from the previous month (MAX) as a proxy for lottery-like features. To mitigate the seemingly arbitrary choice on a single day of maximum return, those authors also examine alternative constructions of MAX (N) based on the average of the top $\mathrm{N}(\mathrm{N}=2,3,4$, and 5) daily returns over the last month. Following their method, we also replace MAX by $\operatorname{MAX}(\mathrm{N})(\mathrm{N}=2,3,4$, and 5) to determine whether our main results hold across these alternative specifications of MAX.

\section{[TABLE 9 HERE]}

Table 9 presents the double-sorting results based on MAX (N) and the individual investor preference index. The patterns obtained here resemble our main results in Table 3, showing that MAX (N) only negatively and significantly predicts the cross-section of stock returns among stocks preferred by individual investors. The predictability decreases with the drop of individual investor preference index. These return patterns are robust under all factor models.

\section{[TABLE 10 HERE]}


In Table 10, we provide Fama-MacBeth regression results on the interactions of MAX(N) and the preference index. Similar to the double-sorting results in Table 9 and the firm-level regressions in Table 4, the time-series average coefficients on MAX(N) are only negatively significant among stocks with a high individual investor preference index.

The results in Tables 9 and 10 show that our main results are robust under alternative specifications of MAX that skewness/lottery-like features only negatively predict the crosssection of stock returns among stocks that are preferred by individual investors.

\subsection{Ruling out the Circularity Concern}

One might have a circularity concern that since some individual investors are also shown to have a preference for stocks with high skewness, sorting stocks based on the individual preference index might yield the same results as those based on the lottery-like measures. We argue that the return predictability of lottery-like features and the individual investor preference are related but not the same. We mitigate this concern through the following discussions. First, the individual investor preference index itself does not predict stock returns. As we can observe from Table 11, although the portfolio returns exhibit a mild declining pattern as the individual investor preference index increases, the high-minus-low difference in raw returns $(-0.37)$ is not statistically significant $(\mathrm{t}$-stat $=-0.94)$. The trend is not strictly monotonic either, with the highest (lowest) portfolio return appearing in the third (ninth) decile. The factor-adjusted returns are mostly small and statistically insignificant, except for the Fama-French three-factor adjusted returns. Meanwhile, not all stock characteristics that are used to construct the preference index predict stock returns. Although some of them do have return predictability, the direction of the predictability is sometimes contradictory. For example, Barber and Odean (2000) shows that individual investors prefer stocks with a high market beta, low market capitalization, and a high book-to-market ratio. Market beta has been shown to negatively predict the cross-section of stock returns, while small firms and value firms are shown to earn premiums. Price-level and dividend 
payment (both included in the preference index), to the best of our knowledge, do not exhibit return predictability in the literature.

Along with our main results of double sorting portfolios, we provide evidence that only stocks preferred by individual investors exhibit a negative relation between lottery-like features and subsequent stock returns. For example, two stocks (stock A and stock B) both have lottery-like features. Stock A has characteristics that attract individual investors, such as a low price and a small size, while stock B has a high price and a large size. We argue and provide evidence that only stock A would have a negative relation between its MAX/skewness and subsequent stock returns.

Second, the theoretical foundations behind the return predictabilities for the lottery-like measure and some stock characteristics preferred by retail investors are also different. Mitton and Vorkink (2007) model the negative predictability of skewness by introducing the skewness preference in the utility function, while Barberis and Huang (2008) rely on the prospect theory and show that a biased probability-weighting function leads to a similar asset pricing implication. Both theories can be linked to individual investors. However, the return predictability of some stock characteristics preferred by individual investors is not originated from individual investors' preference or behavior. For example, Frazzinia and Pedersen (2014) links funding constraints to high market beta stocks, while Zhang (2005) introduces costly reversibility and countercyclical price of risk in his model to generate value premium.

Third, as reported in Table 2, the monthly average cross-sectional correlation between MAX and the individual investor preference index is approximately 30\%. This indicates that although they are partially overlapped, MAX and the individual investor preference index capture a substantial amount of different information. Due to the correlation between these two variables, we conduct independent double sorts throughout the paper so that the benchmarks for "High 
(Low) MAX” are consistent across all preference index portfolios and that the benchmarks for “High (Low) Preference Index” are consistent across all MAX portfolios.

Fourth, the existing literature based on account-level data shows that the average individual investors' portfolios underperform the market in the long-run, both before and after costs (for example, Barber and Odean, 2000; Grinblatt and Keloharju, 2000; Barber, Odean, Zhu, 2009). The crucial point here is that it is the individual investors who lose money over time; it is not that the stocks they prefer underperform in the cross-section. Moreover, Kaniel, Saar, and Titman (2008) and Kaniel et al. (2012) document that individual investors' trading positively predicts short-run returns. Hence, to our knowledge, there is no conclusive and comprehensive evidence that stocks preferred or heavily traded by individual investors underperform.

Based on the above arguments, we believe that the circularity concern in our paper is largely mitigated, and the lottery-like features predict stock returns only via the channel of individual investors.

\section{Conclusion}

In this paper, we find a robust negative relation between skewness/lottery-like features, proxied by maximum return (MAX) over the last month, and future returns for stocks preferred by individual investors. This negative relation is nonexistent for the rest of stocks.

We construct a composite index that captures individual investor preference by bundling ten stock characteristics that are associated with the concentration of individual investors: 1) institutional ownership (Kumar and Lee, 2006); 2) small trade fraction (Han and Kumar, 2013); 3) price level (Kumar, 2009); 4) idiosyncratic volatility (Kumar, 2009); 5) market capitalization (Barber and Odean, 2000; Gao and Lin, 2015; Gompers and Metrick, 2001); 6) profitability (Gao and Lin, 2015); 7) book-to-market ratio (Barber and Odean, 2000); 8) market beta (Barber and 
Odean, 2000); 9) abnormal trading volume (Barber and Odean, 2008); and 10) dividend payments (Graham and Kumar, 2006).

The findings hold at both the portfolio and firm levels. Meanwhile, the negative relation between maximum daily return over the last month and subsequent return is produced by the stocks preferred by individuals that account for less than $5 \%$ of the overall market capitalization. The subsample analysis and subsequent trading pattern both point to the same conclusion that the return predictability of skewness is concentrated on stocks preferred by individual investors.

Finally, our results are robust to measures of skewness, including total, idiosyncratic, and expected skewness constructed using various past return windows. Our results also hold when we use alternative definitions of maximum daily return over the last month, and the individual investor preference index alone does not robustly predict stock return, which mitigates the circularity concern. 


\section{Appendix. Variable Definitions}

ACCRUALS: Accruals is calculated following Sloan (1996).

ASSETG: Assetg is the quarterly asset growth rate. Following Cooper, Gulen, and Schill (2008), asset growth is defined as the growth rate of total assets, i.e., $\Delta$ ATQ /ATQ.

BEME: BEME is book-to-market ratio, defined as book equity over market equity.

BETA: Beta is market beta. We use the lag and lead of both the market portfolio and the current portfolio when estimating market beta to take into account nonsynchronous trading, following Scholes and Williams (1977) and Dimson (1979):

$$
R_{\mathrm{i}, \mathrm{d}}-r_{\mathrm{f}, \mathrm{d}}=\alpha_{\mathrm{i}}+\beta_{1, \mathrm{i}}\left(R_{\mathrm{m}, \mathrm{d}-1}-r_{\mathrm{f}, \mathrm{d}-1}\right)+\beta_{2, \mathrm{i}}\left(R_{\mathrm{m}, \mathrm{d}}-r_{\mathrm{f}, \mathrm{d}}\right)+\beta_{3, \mathrm{i}}\left(R_{\mathrm{m}, \mathrm{d}+1}-r_{\mathrm{f}, \mathrm{d}+1}\right)+\varepsilon_{\mathrm{i}, \mathrm{d}}
$$

where $R_{\mathrm{i}, \mathrm{d}}$ is the return of stock $\mathrm{i}$ on day $\mathrm{d}, R_{\mathrm{m}, \mathrm{d}}$ is the market return on day d, and $r_{\mathrm{f}, \mathrm{d}}$ is the riskfree rate on day $\mathrm{d}$. We estimate the beta for each stock using daily returns every month. The market beta of stock $\mathrm{i}$ in month $\mathrm{t}$ is defined as the sum of three beta coefficients.

COSKEW: COSKEW is coskewness, defined as follows:

$$
\operatorname{COSKEW~}_{\mathrm{i}, \mathrm{t}}=\Sigma_{\mathrm{d}}\left(\left(R_{\mathrm{i}, \mathrm{d}}-\mu_{\mathrm{i}}\right)\left(R_{\mathrm{m}, \mathrm{d}}-\mu_{\mathrm{m}}\right)^{2} / \sigma_{\mathrm{i}} \sigma_{\mathrm{m}}{ }^{2}\right) / D_{\mathrm{t}}, \mathrm{d}=1, \ldots, D_{\mathrm{t}} .
$$

where $R_{\mathrm{i}, \mathrm{d}}$ is the return of stock $\mathrm{i}$ on day $\mathrm{d}, R_{\mathrm{m}, \mathrm{d}}$ is the market return on day $\mathrm{d}, \mu_{\mathrm{i}}$ is the average daily returns for stock $\mathrm{i}, \mu_{\mathrm{m}}$ is the average daily market return, $\sigma_{\mathrm{i}}$ is the standard deviation of daily returns for stock $\mathrm{i}$, and $\sigma_{\mathrm{m}}$ is the standard deviation of daily market returns. We estimate coskewness each month using daily returns from the past 12 months.

EISKEW: EISKEW is the expected idiosyncratic skewness in Boyer, Mitton, and Vorkink (2010).

ILLIQ: ILLIQ is an illiquidity measure following Amihud (2002), the monthly average ratio of absolute daily return over daily trading volume. We require a minimum of 10 non-missing daily trading volumes to calculate this illiquidity proxy.

ISKEW: ISKEW is idiosyncratic skewness, which is a scaled measure of the third moment of residuals obtained by fitting a factor model to the daily stock returns time series. Following Kumar (2009) and Bali, Cakici, and Whitelaw (2011), we construct ISKEW over the previous 6 
months and 12 months by using a two-factor model following Harvey and Siddique (2000). Specifically, ISKEW is the third moment of residuals from the following regression for each stock:

$$
R_{\mathrm{i}, \mathrm{d}}-r_{\mathrm{f}, \mathrm{d}}=\alpha_{\mathrm{i}}+\beta_{\mathrm{i}}\left(R_{\mathrm{m}, \mathrm{d}}-r_{\mathrm{f}, \mathrm{d}}\right)+\gamma_{\mathrm{i}}\left(R_{\mathrm{m}, \mathrm{d}}-r_{\mathrm{f}, \mathrm{d}}\right)^{2}+\varepsilon_{\mathrm{i}, \mathrm{d}}
$$

where $R_{\mathrm{i}, \mathrm{d}}$ is the return of stock $\mathrm{i}$ on day d, $R_{\mathrm{m}, \mathrm{d}}$ is the market return on day d, $r_{\mathrm{f}, \mathrm{d}}$ is the risk-free rate on day $\mathrm{d}$, and $\varepsilon_{\mathrm{i}, \mathrm{d}}$ is the idiosyncratic return on $\mathrm{d}$.

We construct ISKEW over the previous 60 months using the Fama and French (1993) threefactor model, following Boyer, Mitton, and Vorkink (2010).

IVOL: IVOL is idiosyncratic volatility. Following Kumar (2009), we estimate idiosyncratic volatility as the variance of the residual obtained by fitting a four-factor model to the daily stock return time-series over the past six months.

MAX: MAX is the maximum daily return within a month following Bali, Cakici, and Whitelaw (2011):

$$
\operatorname{MAX} X_{\mathrm{i}, \mathrm{t}}=\max \left(R_{\mathrm{i}, \mathrm{d}}\right), \mathrm{d}=1, \ldots, D_{\mathrm{t}}
$$

where $R_{\mathrm{i}, \mathrm{d}}$ is the return of stock i on day $\mathrm{d}$ and $D_{\mathrm{t}}$ is the number of trading days in month $\mathrm{t}$.

$\operatorname{MAX}(\mathbf{N})$ : The average top $\mathrm{N}(\mathrm{N}=2,3,4,5)$ daily returns within a month, following Bali, Cakici, and Whitelaw (2011).

MOM: Following Jegadeesh and Titman (1993), the momentum variable for each stock in month $\mathrm{t}$ is defined as the cumulative return on the stock from month $\mathrm{t}-12$ to month $\mathrm{t}-2$.

NS: NS is net stock issuance. Following Pontiff and Woodgate (2008), net stock issuance is defined as the change in the natural log of split-adjusted shares outstanding.

PROFITABILITY: We adopt five measures to proxy for profitability and bundle them into a profitability ranking as one of the ingredients of the individual investor preference index. These five measures are as follows: 1) earnings per share (EPSPIQ); 2) net income (NIQ) over total assets (ATQ); 3) return on equity, defined as income before extraordinary items (IBQ) over book equity; 4) return on assets, defined as income before extraordinary items (IBQ) over total assets 
(ATQ); and 5) gross profit, the difference between revenue (REVTQ) and costs of goods sold (COGSQ), divided by total assets (ATQ).

SIZE: Size is firm size, measured by the natural logarithm of the market value of equity.

STREV: STREV is short-term reversal, defined as the return on the stock over the previous month, following Jegadeesh (1990) and Lehmann (1990).

TSKEW: TSKEW is total skewness, which is a scaled measure of the third moment of daily return time series:

$$
\left.\operatorname{TSKEW}_{\mathrm{i}, \mathrm{t}}=\Sigma_{\mathrm{d}}\left(\left(R_{\mathrm{i}, \mathrm{d}}-\mu_{\mathrm{i}}\right) / \sigma_{\mathrm{i}}\right)^{3}\right) / D_{\mathrm{t}}, \mathrm{d}=1, \ldots, D_{\mathrm{t}} .
$$

where $R_{\mathrm{i}, \mathrm{d}}$ is the return of stock i on day d and $D_{\mathrm{t}}$ is the number of trading days, $\mu_{\mathrm{i}}$ is the mean of daily returns for stock $\mathrm{i}$, and $\sigma_{\mathrm{i}}$ is the standard deviation of daily returns for stock $\mathrm{i}$. We construct TSKEW over the previous 6 months, 12 months, and 60 months.

TURNOVER: Turnover is defined as the monthly average of daily trading volume over shares outstanding. 


\section{Reference}

Amihud, Y. (2002) Illiquidity and stock returns: cross-section and time-series effects, Journal of Financial Markets 5, 31-56.

An, L., Wang, H., Wang, J., and Yu, J. (2015) Lottery-related anomalies: the role of referencedependent preferences. PBCSF-NIFR Research Paper No. 15-04.

Avramov, D., Chordia, T., Jostova, G., and Philipov, A. (2007) Momentum and credit rating, The Journal of Finance 62, 2503-2520.

Bali, T. G., Brown, S., Murray, S., and Tang, Y. (2014) Betting against beta or demand for lottery. Georgetown McDonough School of Business Research Paper No. 2408146.

Bali, T. G., Cakici, N., and Whitelaw, R. F. (2011) Maxing out: stocks as lotteries and the crosssection of expected returns, Journal of Financial Economics 99, 427-446.

Barber, B. M. and Odean, T. (2000) Trading is hazardous to your wealth: the common stock investment performance of individual investors, The Journal of Finance 55, 773-806.

Barber, B. M. and Odean, T. (2008) All that glitters: the effect of attention and news on the buying behavior of individual and institutional investors, Review of Financial Studies 21, 785-818.

Barber, B. M., Odean, T., and Zhu, N. (2009) Do retail trades move markets?, Review of Financial Studies 22, 151-186.

Barberis, N. and Huang, M. (2008) Stocks as lotteries: the implications of probability weighting for security prices, American Economic Review 98, 2066-2100. 
Battalio, R. H. and Mendenhall, R. R. (2005) Earnings expectations, investor trade size, and anomalous returns around earnings announcements, Journal of Financial Economics 77, 289-319.

Boyer, B., Mitton, T., and Vorkink, K. (2010) Expected idiosyncratic skewness, Review of Financial Studies 23, 169-202.

Brandt, M. W., Brav, A., Graham, J. R., and Kumar, A. (2010) The idiosyncratic volatility puzzle: time trend or speculative episodes?, Review of Financial Studies 23, 863-899.

Brown, K. C., Harlow, W. V., and Starks, L. T. (1996) Of tournaments and temptations: an analysis of managerial incentives in the mutual fund industry, The Journal of Finance 51, 85-110.

Brunnermeier, M. K., Gollier, C., and Parker, J. A. (2007) Optimal beliefs, asset prices, and the preference for skewed returns, American Economic Review 97, 159-165.

Brunnermeier, M. K., and Parker, J. A. (2005) Optimal expectations, American Economic Review 95, 1092-1118.

Campbell, J. Y., Ramadorai, T., and Schwartz, A. (2009) Caught on tape: institutional trading, stock returns, and earnings announcements, Journal of Financial Economics 92, 66-91.

Carhart, M. M. (1997) On persistence in mutual fund performance, The Journal of Finance 52, $57-82$

Chen, J., Hong, H., and Stein, J. C. (2001) Forecasting crashes: Trading volume, past returns, and conditional skewness in stock prices, Journal of Financial Economics 61, 345-381. 
Chen, H. and Pennacchi, G. G. (2009) Does prior performance affect a mutual fund's choice of risk? Theory and further empirical evidence, Journal of Financial and Quantitative Analysis 44, 745-775.

Cooper, M. J., Gulen, H., and Schill, M. J. (2008) Asset growth and the cross-section of stock returns, The Journal of Finance 63, 1609-1651.

Derrien, F. (2005) IPO pricing in "hot" market conditions: who leaves money on the table?, The Journal of Finance 60, 487-521.

Dimson, E. (1979) Risk measurement when shares are subject to infrequent trading, Journal of Financial Economics 7, 197-226.

Fama, E. F. and French, K. R. (1993) Common risk factors in the returns on stocks and bonds, Journal of Financial Economics 33, 3-56.

Fama, E. F. and French, K. R. (2015) A five-factor asset pricing model, Journal of Financial Economics 116, 1-22.

Fama, E. F. and MacBeth, J. D. (1973) Risk, return, and equilibrium: empirical tests, Journal of Political Economy 81, 607-636.

Frazzini, A. and Pedersen, L. H. (2014) Betting against beta, Journal of Financial Economics, 111, $1-25$.

Gao, X. and Lin, T. C. (2015) Do individual investors treat trading as a fun and exciting gambling activity? Evidence from repeated natural experiments, Review of Financial Studies 28, 2128-2166.

Gompers, P. A. and Metrick, A. (2001) Institutional investors and equity prices, Quarterly Journal of Economics 116, 229-259. 
Graham, J. R. and Kumar, A. (2006) Do dividend clienteles exist? Evidence on dividend preferences of retail investors, The Journal of Finance 61, 1305-1336.

Grinblatt, M. and Keloharju, M. (2000) The investment behavior and performance of various investor types: a study of Finland's unique data set, Journal of Financial Economics 55, 43-67.

Han, B. and Kumar, A. (2013) Speculative retail trading and asset prices, Journal of Financial and Quantitative Analysis 48, 377-404.

Harvey, C. R. and Siddique, A. (1999) Autoregressive conditional skewness, Journal of Financial and Quantitative Analysis 34, 465-487.

Harvey, C. R. and Siddique, A. (2000) Conditional skewness in asset pricing tests, The Journal of Finance 55, 1263-1295.

Hvidkjaer, S. (2006) A trade-based analysis of momentum, Review of Financial Studies 19, 457491.

Hvidkjaer, S. (2008) Small trades and the cross-section of stock returns, Review of Financial Studies 21, 1123-1151.

Jegadeesh, N. (1990) Evidence of predictable behavior of security returns, The Journal of Finance 45, 881-898.

Jegadeesh, N. and Titman, S. (1993) Returns to buying winners and selling losers: implications for stock market efficiency, The Journal of Finance 48, 65-91.

Kaniel, R., Saar, G., and Titman, S. (2008) Individual investor trading and stock returns. The Journal of Finance 63, 273-310. 
Kaniel, R., Liu, S., Saar, G., and Titman, S. (2012) Individual investor trading and return patterns around earnings announcements, The Journal of Finance 67, 639-680.

Kempf, A., Ruenzi, S., and Thiele, T. (2009) Employment risk, compensation incentives, and managerial risk taking: evidence from the mutual fund industry, Journal of Financial Economics 92, 92-108.

Koski, J. L. and Pontiff, J. (1999) How are derivatives used? Evidence from the mutual fund industry, The Journal of Finance 54, 791-816.

Kumar, A. (2009) Who gambles in the stock market?, The Journal of Finance 64, 1889-1933.

Kumar, A. and Lee, C. (2006) Retail investor sentiment and return comovements, The Journal of Finance 61, 2451-2486.

Kumar, A. and Page, J. K. (2014) Deviations from norms and informed trading, Journal of Financial and Quantitative Analysis 49, 1005-1037.

Kumar, A., Page, J. K., and Spalt, O. G. (2011) Religious beliefs, gambling attitudes, and financial market outcomes, Journal of Financial Economics 102, 671-708.

Lee, C. and Ready, M. J. (1991) Inferring trade direction from intraday data, The Journal of Finance 46, 733-746.

Lee, C. M. and Radhakrishna, B. (2000) Inferring investor behavior: evidence from TORQ data, Journal of Financial Markets 3, 83-111.

Lehmann, B. N. (1990) Fads, martingales, and market efficiency, Quarterly Journal of Economics 105, 1-28.

Lou, D. (2014) Attracting investor attention through advertising, Review of Financial Studies 27, 1797-1829. 
Malmendier, U. and Shanthikumar, D. (2007) Are small investors naive about incentives?, Journal of Financial Economics 85, 457-489.

Malmendier, U. and Shanthikumar, D. (2014) Do security analysts speak in two tongues?, Review of Financial Studies 27, 1287-1322.

Mitton, T. and Vorkink, K. (2007) Equilibrium underdiversification and the preference for skewness, Review of Financial Studies 20, 1255-1288.

Ofek, E. and Richardson, M. (2003) Dotcom mania: the rise and fall of internet stock prices, The Journal of Finance 58, 1113-1137.

Pontiff, J. and Woodgate, A. (2008) Share issuance and cross-sectional returns, The Journal of Finance 63, 921-945.

Scholes, M. and Williams, J. (1977) Estimating betas from nonsynchronous data, Journal of Financial Economics 5, 309-327.

Sloan, R. (1996) Do stock prices fully reflect information in accruals and cash flows about future earnings?, Accounting review 71, 289-315.

Stambaugh, R. F., Yu, J., and Yuan, Y. (2015) Arbitrage asymmetry and the idiosyncratic volatility puzzle, The Journal of Finance 70, 1903-1948.

Yuan, Y. (2015) Market-wide attention, trading, and stock returns, Journal of Financial Economics 116, 548-564.

Zhang, Y. (2005) Individual skewness and the cross-section of expected returns, Unpublished working paper, Yale University. 
Table 1

Summary Statistics for quintiles portfolios of stocks sorted by MAX

This table reports the time series averages of the characteristics of quintile portfolios sorted on MAX. Monthly maximum daily return (MAX) is constructed following Bali, Cakici, and Whitelaw (2011). Individual preference index is a composite rank based on ten stock characteristics preferred by individual investors: 1) institutional ownership, the sum of percentage holdings by institutional investors with 13F filling; 2) Small trade percent, the ratio of total small trade volume over total trading volume for each stock in each month; 3) profitability rank, a composite rank based on five profit measures (earnings per share, ROE, ROA, net income, and gross profit); 4) size, the natural log of market capitalization; 5) price level, the absolute value of price; 6) idiosyncratic volatility, the standard error of the residual obtained by fitting a four-factor model to the previous six months' daily stock returns; 7) book-to-market ratio, book value of equity over market value of equity; 8) market beta, constructed monthly using daily returns following Scholes (1977) and Dimson (1979) to take into account nonsynchronous trading; 9) abnormal trading volume, the monthly maximum daily trading volume over the average daily trading volume from the past 12 months; 10) dividend payment, a dummy variable that equals one if the stock has paid dividend in the past twelve months. All accounting variables are quarterly updated and lagged for two months to ensure availability. Control variables include: momentum, the cumulative return from the past twelve months; short-term reversal, proxied by return in the previous month; illiquid, the average ratio of the absolute daily stock returns to its dollar trading volume, as outlined by Amihud (2002); coskewness with market is constructed by daily return from the past 12 months; net stock issuance, the change in the natural log of split-adjusted shares outstanding; the growth rate of total assets; accruals following Sloan (1996); average daily turnover ratio within each month. The sample includes all common share stocks traded in NYSE, AMEX and NASDAQ and covers January 1976 to December 2014, expect for institutional ownership and small trade percent. Institutional ownership starts in January 1981. Small trade percent starts in 1993 and ends pre-2000 due to data availability, the introduction of decimalization, and growing use of computerized trading algorithms.

\begin{tabular}{|c|c|c|c|c|c|}
\hline \multirow[b]{2}{*}{ Characteristics } & \multicolumn{5}{|c|}{ Maximum Daily Return Quintiles } \\
\hline & Low & 2 & 3 & 4 & High \\
\hline MAX (\%) & 2.03 & 3.81 & 5.57 & 8.26 & 18.38 \\
\hline \multicolumn{6}{|c|}{ Characteristics Preferred by Individual Investors } \\
\hline Individual Preference Index & 25.10 & 37.31 & 48.05 & 59.52 & 74.07 \\
\hline Institutional Ownership & 0.40 & 0.43 & 0.38 & 0.32 & 0.22 \\
\hline Small Trade Fraction & 0.06 & 0.09 & 0.13 & 0.21 & 0.36 \\
\hline Profitability Rank & 44.01 & 43.06 & 46.28 & 51.62 & 60.83 \\
\hline Size (\$ Billion) & 3.89 & 2.38 & 1.32 & 0.69 & 0.31 \\
\hline Price Level (\$) & 51.81 & 30.21 & 21.43 & 14.92 & 8.62 \\
\hline Idiosyncratic Volatility (\%) & 1.82 & 2.21 & 2.86 & 3.71 & 5.78 \\
\hline Book-to-Market Ratio & 0.88 & 0.82 & 0.83 & 0.87 & 1.06 \\
\hline Beta & 0.42 & 0.69 & 0.86 & 1.08 & 1.20 \\
\hline Abnormal Trading Volume & 4.30 & 4.22 & 4.61 & 5.23 & 8.91 \\
\hline Dividend Payment (\%) & 0.66 & 0.61 & 0.47 & 0.34 & 0.20 \\
\hline \multicolumn{6}{|l|}{ Control Variables } \\
\hline Momentum (\%) & 15.05 & 14.67 & 12.37 & 10.76 & 6.54 \\
\hline Short-term Reversal (\%) & -2.76 & -1.10 & -0.12 & 1.58 & 8.40 \\
\hline Illiquidity $\left(10^{6}\right)$ & 2.55 & 1.49 & 2.75 & 6.42 & 33.44 \\
\hline Coskewness with Market & -0.12 & -0.12 & -0.11 & -0.10 & -0.08 \\
\hline Net Stock Issuance (\%) & 0.68 & 0.89 & 1.19 & 1.55 & 2.03 \\
\hline Asset Growth (\%) & 5.69 & 4.26 & 4.88 & 5.14 & 5.91 \\
\hline Accruals (\%) & -0.77 & -0.72 & -0.66 & -0.66 & -1.22 \\
\hline Turnover Ratio & 0.30 & 0.40 & 0.48 & 0.55 & 0.71 \\
\hline
\end{tabular}




\section{Table 2}

Correlation matrix on stock characteristics preferred by individual investors

This table reports the time series averages of cross-sectional correlation matrix. Monthly maximum daily return (MAX) is constructed following Bali, Cakici, and Whitelaw (2011). Individual preference index is a composite rank based on ten stock characteristics preferred by individual investors: 1) institutional ownership, the sum of percentage holdings by institutional investors with 13F filling; 2) Small trade percent, the ratio of total small trade volume over total trading volume for each stock in each month; 3) profitability rank, a composite rank based on five profit measures (earnings per share, ROE, ROA, net income, and gross profit); 4) size, the natural log of market capitalization; 5) price level, the absolute value of price; 6) idiosyncratic volatility, the standard error of the residual obtained by fitting a four-factor model to the previous six months' daily stock returns; 7) book-to-market ratio, book value of equity over market value of equity; 8) market beta; 9) abnormal trading volume, the monthly maximum daily trading volume over the average daily trading volume from the past 12 months; 10) dividend payment, a dummy variable that equals one if the stock has paid dividend in the past twelve months. TSKEW(6m) is the return skewness for each stock from the past six months. ISKEW $(6 \mathrm{~m})$ is the skewness of the residual obtained by fitting a two-factor model to the daily stock returns time series, where the two factors are the excess market returns and the squared excess market returns, as outlined by Harvey and Siddique (2000). Previous six months of daily returns are used to construct this measure. TSKEW(12m) is the return skewness for each stock from the past twelve months. ISKEW(12M) is also constructed following Harvey and Siddique but using daily returns from the previous twelve months. TSKEW(60m) is the return skewness for each stock from the past sixty months. ISKEW(60m) is the skewness of the residual obtained by fitting Fama and French three-factor model to the daily stock returns from the past sixty months. EISKEW follows Boyer, Mitton, and Vorkink (2010).

\begin{tabular}{|c|c|c|c|c|c|c|c|c|c|c|c|c|c|c|c|c|c|c|c|}
\hline & MAX & $\begin{array}{l}\text { Preference } \\
\text { Index }\end{array}$ & $\begin{array}{l}\text { Institutional } \\
\text { Ownership }\end{array}$ & $\begin{array}{l}\text { Small } \\
\text { Trade } \\
\text { Percent }\end{array}$ & $\begin{array}{c}\text { Profitability } \\
\text { Rank }\end{array}$ & Size & $\begin{array}{l}\text { Price } \\
\text { Level }\end{array}$ & Idio.Vol & $\begin{array}{c}\text { Book-to- } \\
\text { Market }\end{array}$ & $\begin{array}{l}\text { Dividend } \\
\text { Payment }\end{array}$ & $\begin{array}{l}\text { Market } \\
\text { Beta }\end{array}$ & $\begin{array}{l}\text { Abn.Trading } \\
\text { Volume }\end{array}$ & $\begin{array}{c}\text { TSKEW } \\
(6 \mathrm{~m})\end{array}$ & $\begin{array}{l}\text { ISKEW } \\
(6 \mathrm{~m})\end{array}$ & $\begin{array}{l}\text { TSKEW } \\
(12 \mathrm{~m})\end{array}$ & $\begin{array}{l}\text { ISKEW } \\
(12 \mathrm{~m})\end{array}$ & $\begin{array}{l}\text { TSKEW } \\
\text { (60m) }\end{array}$ & $\begin{array}{l}\text { ISKEW } \\
(60 \mathrm{~m})\end{array}$ & EISKEW \\
\hline MAX & 1 & & & & & & & & & & & & & & & & & & \\
\hline $\begin{array}{l}\text { Preference } \\
\text { Index }\end{array}$ & 0.33 & 1 & & & & & & & & & & & & & & & & & \\
\hline $\begin{array}{l}\text { Institution } \\
\text { Ownership }\end{array}$ & -0.23 & -0.65 & 1 & & & & & & & & & & & & & & & & \\
\hline $\begin{array}{l}\text { Small Trade } \\
\text { Percent }\end{array}$ & 0.44 & 0.77 & -0.51 & 1 & & & & & & & & & & & & & & & \\
\hline $\begin{array}{l}\text { Profitability } \\
\text { Rank }\end{array}$ & -0.23 & -0.61 & 0.30 & -0.34 & 1 & & & & & & & & & & & & & & \\
\hline Size & -0.29 & -0.76 & 0.66 & -0.67 & 0.38 & 1 & & & & & & & & & & & & & \\
\hline $\begin{array}{l}\text { Price } \\
\text { Level }\end{array}$ & -0.10 & -0.34 & 0.12 & -0.13 & 0.15 & 0.27 & 1 & & & & & & & & & & & & \\
\hline Idio.Vol & 0.64 & 0.62 & -0.39 & 0.62 & -0.36 & -0.51 & -0.17 & 1 & & & & & & & & & & & \\
\hline $\begin{array}{l}\text { Book-to- } \\
\text { Market }\end{array}$ & 0.08 & 0.33 & -0.13 & 0.14 & -0.20 & -0.23 & -0.09 & 0.02 & 1 & & & & & & & & & & \\
\hline $\begin{array}{l}\text { Dividend } \\
\text { Payment }\end{array}$ & -0.25 & -0.64 & 0.21 & -0.30 & 0.30 & 0.41 & 0.12 & -0.42 & 0.03 & 1 & & & & & & & & & \\
\hline $\begin{array}{l}\text { Market } \\
\text { Beta }\end{array}$ & 0.07 & -0.21 & 0.11 & -0.07 & 0.03 & 0.11 & 0.01 & 0.02 & -0.06 & -0.02 & 1 & & & & & & & & \\
\hline $\begin{array}{l}\text { Abn.Tradin } \\
\text { g Volume }\end{array}$ & 0.25 & 0.01 & -0.08 & -0.03 & -0.03 & -0.11 & -0.02 & 0.11 & 0.02 & -0.03 & -0.02 & 1 & & & & & & & \\
\hline $\begin{array}{l}\text { TSKEW } \\
\text { (6m) }\end{array}$ & 0.26 & 0.15 & -0.16 & 0.14 & -0.06 & -0.14 & -0.03 & 0.28 & 0.05 & -0.09 & -0.01 & 0.09 & 1 & & & & & & \\
\hline $\begin{array}{l}\text { ISKEW } \\
(6 \mathrm{~m})\end{array}$ & 0.24 & 0.13 & -0.14 & 0.12 & -0.05 & -0.13 & -0.02 & 0.26 & 0.04 & -0.08 & -0.01 & 0.08 & 0.97 & 1 & & & & & \\
\hline
\end{tabular}


(Continued)

\begin{tabular}{|c|c|c|c|c|c|c|c|c|c|c|c|c|c|c|c|c|c|c|c|}
\hline & MAX & $\begin{array}{l}\text { Preference } \\
\text { Index }\end{array}$ & $\begin{array}{l}\text { Institutional } \\
\text { Ownership }\end{array}$ & $\begin{array}{c}\text { Small } \\
\text { Trade } \\
\text { Percent } \\
\end{array}$ & $\begin{array}{l}\text { Profitability } \\
\text { Rank }\end{array}$ & Size & $\begin{array}{l}\text { Price } \\
\text { Level }\end{array}$ & Idio.Vol & $\begin{array}{l}\text { Book-to- } \\
\text { Market }\end{array}$ & $\begin{array}{l}\text { Dividend } \\
\text { Payment }\end{array}$ & $\begin{array}{l}\text { Market } \\
\text { Beta }\end{array}$ & $\begin{array}{l}\text { Abn.Trading } \\
\text { Volume }\end{array}$ & $\begin{array}{l}\text { TSKEW } \\
\text { (6m) }\end{array}$ & $\begin{array}{l}\text { ISKEW } \\
(6 \mathrm{~m})\end{array}$ & $\begin{array}{c}\text { TSKEW } \\
\text { (12m) }\end{array}$ & $\begin{array}{c}\text { ISKEW } \\
(12 \mathrm{~m})\end{array}$ & $\begin{array}{c}\text { TSKEW } \\
\text { (60m) }\end{array}$ & $\begin{array}{l}\text { ISKEW } \\
(60 \mathrm{~m})\end{array}$ & EISKEW \\
\hline $\begin{array}{l}\text { TSKEW } \\
\text { (12m) }\end{array}$ & 0.23 & 0.18 & -0.21 & 0.18 & -0.09 & -0.20 & -0.04 & 0.29 & 0.04 & -0.11 & -0.02 & 0.09 & 0.7 & 0.67 & 1 & & & & \\
\hline $\begin{array}{l}\text { ISKEW } \\
(12 \mathrm{~m})\end{array}$ & 0.22 & 0.16 & -0.19 & 0.16 & -0.08 & -0.18 & -0.03 & 0.27 & 0.03 & -0.10 & -0.02 & 0.08 & 0.69 & 0.69 & 0.98 & 1 & & & \\
\hline $\begin{array}{l}\text { TSKEW } \\
\text { (60m) }\end{array}$ & 0.21 & 0.28 & -0.29 & 0.27 & -0.14 & -0.32 & -0.05 & 0.31 & 0.05 & -0.18 & -0.03 & 0.08 & 0.31 & 0.29 & 0.47 & 0.45 & 1 & & \\
\hline $\begin{array}{l}\text { ISKEW } \\
(60 \mathrm{~m})\end{array}$ & 0.20 & 0.25 & -0.27 & 0.26 & -0.13 & -0.29 & -0.05 & 0.29 & 0.04 & -0.16 & -0.03 & 0.07 & 0.31 & 0.3 & 0.47 & 0.46 & 0.99 & 1 & \\
\hline EISKEW & 0.38 & 0.43 & -0.49 & 0.53 & -0.33 & -0.63 & -0.04 & 0.55 & 0.20 & -0.38 & -0.06 & 0.08 & 0.21 & 0.19 & 0.28 & 0.27 & 0.53 & 0.51 & 1 \\
\hline
\end{tabular}


Table 3

Double sorts on maximum daily returns and the individual investor preference index

This table shows the value-weighted average returns to portfolios double sorted on maximum daily returns within each month and the individual investor preference index, as well as the results of time series regressions of high-minus-low portfolio returns on Fama and French factors [market, size, value, RMW, CMA] and Carhart's momentum factor. Newey-West adjusted test statistics are reported in brackets. Univariate sorting results on the maximum daily returns with each month are presented in the first row. All portfolios are sorted and rebalanced at month end based on whole sample breaks. Monthly maximum daily return is based on Bali, Cakici, and Whitelaw (2011). Individual preference index is a composite rank based on ten stock characteristics preferred by individual investors and covers January 1976 to December 2014.

\begin{tabular}{|c|c|c|c|c|c|c|c|c|c|c|}
\hline & \multicolumn{5}{|c|}{ Maximum Daily Return Quintiles } & \multicolumn{5}{|c|}{ High MAX - Low MAX } \\
\hline & Low & 2 & 3 & 4 & High & Raw & Alpha_3F & Alpha_4F & Alpha_5F & Alpha_6F \\
\hline \multicolumn{11}{|c|}{ Individual Preference Index } \\
\hline All & 1.09 & 1.10 & 1.13 & 0.95 & 0.56 & $\begin{array}{c}-0.53 \\
(-1.74)\end{array}$ & $\begin{array}{c}-0.96 \\
(-4.73)\end{array}$ & $\begin{array}{c}-0.73 \\
(-3.24)\end{array}$ & $\begin{array}{c}-0.34 \\
(-1.97)\end{array}$ & $\begin{array}{c}-0.25 \\
(-1.29)\end{array}$ \\
\hline Low & 1.06 & 1.07 & 1.10 & 1.17 & 0.97 & $\begin{array}{c}-0.09 \\
(-0.31)\end{array}$ & $\begin{array}{c}-0.17 \\
(-0.66)\end{array}$ & $\begin{array}{c}-0.06 \\
(-0.22)\end{array}$ & $\begin{array}{c}0.32 \\
(1.19)\end{array}$ & $\begin{array}{c}0.34 \\
(1.21)\end{array}$ \\
\hline 2 & 1.27 & 1.29 & 1.12 & 0.95 & 0.84 & $\begin{array}{c}-0.43 \\
(-1.34)\end{array}$ & $\begin{array}{c}-0.58 \\
(-2.40)\end{array}$ & $\begin{array}{c}-0.58 \\
(-2.08)\end{array}$ & $\begin{array}{c}-0.20 \\
(-0.88)\end{array}$ & $\begin{array}{c}-0.24 \\
(-0.95)\end{array}$ \\
\hline 3 & 1.25 & 1.48 & 1.07 & 0.86 & 0.25 & $\begin{array}{c}-1.00 \\
(-2.98)\end{array}$ & $\begin{array}{c}-1.23 \\
(-4.82)\end{array}$ & $\begin{array}{c}-1.10 \\
(-4.10)\end{array}$ & $\begin{array}{c}-0.59 \\
(-2.55)\end{array}$ & $\begin{array}{c}-0.57 \\
(-2.38)\end{array}$ \\
\hline 4 & 1.32 & 1.64 & 1.49 & 0.74 & -0.02 & $\begin{array}{c}-1.34 \\
(-4.33)\end{array}$ & $\begin{array}{c}-1.71 \\
(-7.13)\end{array}$ & $\begin{array}{c}-1.49 \\
(-5.96)\end{array}$ & $\begin{array}{c}-1.10 \\
(-5.25)\end{array}$ & $\begin{array}{c}-1.01 \\
(-4.69)\end{array}$ \\
\hline High & 1.50 & 1.77 & 1.53 & 1.13 & -0.01 & $\begin{array}{c}-1.50 \\
(-4.21)\end{array}$ & $\begin{array}{c}-1.97 \\
(-6.05)\end{array}$ & $\begin{array}{c}-1.72 \\
(-4.62)\end{array}$ & $\begin{array}{l}-1.40 \\
(-4.27)\end{array}$ & $\begin{array}{c}-1.29 \\
(-3.64)\end{array}$ \\
\hline
\end{tabular}


Table 4

Fama and MacBeth regressions of returns on the interactions between maximum daily returns and preference index and control variables

This table shows average slopes and their Newey-West adjusted t-statistics from monthly cross-section regressions to predict stock returns. We consider the interaction of maximum daily returns and the individual investor preference index. I (port=Low) is a dummy variable that equals one if the stock is in the bottom quintile of the preference index, I (port=High) is a dummy variable that equals one if the stock is in the top quintile of the preference index, I (port=2), I (port=3), I (port=4) are defined accordingly. Individual preference index is a composite rank based on ten stock characteristics preferred by individual investors. Control variables includes: 1) market beta, constructed monthly using daily returns following Scholes (1977) and Dimson (1979); 2) size; 3) book-to-market ratio; 4) momentum; 5) short-term reversal; 6) illiquidity, the average ratio of the absolute daily stock returns to its dollar trading volume, as outlined by Amihud (2002); 7) coskewness with market, constructed by daily return from the past 12 months; 8) net stock issuance, the change in the natural log of splitadjusted shares outstanding; 9) the growth rate of total assets; 10) accruals, following Sloan (1996); 11) average daily turnover ratio within each month. The sample includes all common share stocks traded in NYSE, AMEX and NASDAQ and covers January 1976 to December 2014

\begin{tabular}{|c|c|c|c|c|}
\hline Independent Variable & (1) & (2) & (3) & (4) \\
\hline \multirow[t]{2}{*}{ MAX*I(port=1) } & -0.019 & 0.008 & 0.012 & 0.011 \\
\hline & $(-0.85)$ & $(1.01)$ & $(1.25)$ & $(0.97)$ \\
\hline \multirow[t]{2}{*}{ MAX*I(port=2) } & -0.050 & -0.001 & 0.009 & 0.011 \\
\hline & $(-3.34)$ & $(-0.08)$ & $(0.82)$ & (1.29) \\
\hline \multirow[t]{2}{*}{ MAX*I(port=3) } & -0.075 & -0.020 & -0.011 & 0.001 \\
\hline & $(-6.19)$ & $(-1.93)$ & $(-1.19)$ & $(0.11)$ \\
\hline \multirow[t]{2}{*}{ MAX*I(port=4) } & -0.097 & -0.036 & -0.035 & -0.030 \\
\hline & $(-9.27)$ & $(-4.08)$ & $(-3.52)$ & $(-4.55)$ \\
\hline \multirow[t]{2}{*}{ MAX*I(port=5) } & -0.095 & -0.062 & -0.054 & -0.047 \\
\hline & $(-11.72)$ & $(-5.51)$ & $(-5.09)$ & $(-4.52)$ \\
\hline \multirow[t]{2}{*}{ Preference Index } & 0.018 & -0.016 & -0.010 & -0.046 \\
\hline & $(2.72)$ & $(-2.24)$ & $(-1.90)$ & $(-8.46)$ \\
\hline \multirow[t]{2}{*}{ Beta } & & 0.045 & 0.034 & -0.022 \\
\hline & & (1.33) & $(0.99)$ & $(-1.80)$ \\
\hline \multirow[t]{2}{*}{ Size } & & -0.209 & -0.210 & -0.352 \\
\hline & & $(-5.66)$ & $(-5.86)$ & $(-10.18)$ \\
\hline \multirow[t]{2}{*}{ Beme } & & 0.683 & 0.553 & 0.832 \\
\hline & & $(6.60)$ & (6.14) & $(10.21)$ \\
\hline \multirow[t]{2}{*}{ Mom } & & 0.006 & 0.007 & 0.006 \\
\hline & & $(4.06)$ & $(4.50)$ & (4.16) \\
\hline \multirow[t]{2}{*}{ Strev } & & -0.045 & -0.047 & -0.046 \\
\hline & & $(-9.80)$ & $(-10.57)$ & $(-10.91)$ \\
\hline \multirow[t]{2}{*}{ Illiq } & & & 0.024 & 0.017 \\
\hline & & & (3.86) & (2.89) \\
\hline \multirow[t]{2}{*}{ Ivol } & & & -0.143 & -0.125 \\
\hline & & & $(-2.67)$ & $(-1.94)$ \\
\hline \multirow[t]{2}{*}{ Coskew } & & & -0.168 & -0.245 \\
\hline & & & $(-0.77)$ & $(-1.20)$ \\
\hline \multirow[t]{2}{*}{ NS } & & & & -0.022 \\
\hline & & & & $(-3.62)$ \\
\hline \multirow[t]{2}{*}{ Assetg } & & & & 0.007 \\
\hline & & & & (1.19) \\
\hline \multirow[t]{2}{*}{ Accruals } & & & & -0.022 \\
\hline & & & & $(-6.25)$ \\
\hline Turnover & & & & 0.057 \\
\hline
\end{tabular}


Table 5

Unconditional MAX spread over different subsamples

For each month, all stocks in the sample are ranked into decile portfolios based on their maximum daily returns from the previous month. MAX spread is the time-series average returns of buying stocks in the top decile and selling stocks in the bottom decile. Portfolios are value-weighted and rebalanced every month. Each subsequent row in the table represents a monotonically decreasing sample of stocks obtained by sequentially excluding stocks in the highest $5 \%$ individual preference index group. Individual preference index is a composite rank based on ten stock characteristics preferred by individual investors. Newey-West t-statistics are provided in parentheses; The first three columns report four-factor, five-factor, and six-factor adjusted MAX spreads. The fourth column shows the market capitalization of the given subsample as a percentage of the whole sample. The last column provides the average number of firms per month in each subsample. Subsamples on individual preference index cover from January 1976 to December 2014

\begin{tabular}{|c|c|c|c|c|c|}
\hline Stock Samples & 4F Alpha & 5F Alpha & 6F Alpha & Percent of Total Market Cap & Number of Firms \\
\hline \multirow[t]{2}{*}{ All Firms } & -1.05 & -0.53 & -0.42 & 100 & 5255 \\
\hline & $(-3.73)$ & $(-2.39)$ & $(-1.52)$ & & \\
\hline \multirow[t]{2}{*}{ Exclude Top 5\% } & -1.03 & -0.52 & -0.43 & 99.94 & 4990 \\
\hline & $(-3.68)$ & $(-2.37)$ & $(-1.64)$ & & \\
\hline \multirow[t]{2}{*}{ Exclude Top 10\% } & -0.98 & -0.53 & -0.41 & 99.84 & 4726 \\
\hline & $(-3.53)$ & $(-2.28)$ & $(-1.63)$ & & \\
\hline \multirow[t]{2}{*}{ Exclude Top 15\% } & -0.89 & -0.45 & -0.34 & 99.69 & 4462 \\
\hline & $(-3.34)$ & $(-2.06)$ & $(-1.42)$ & & \\
\hline \multirow[t]{2}{*}{ Exclude Top 20\% } & -0.88 & -0.44 & -0.34 & 99.49 & 4199 \\
\hline & $(-3.42)$ & $(-2.13)$ & $(-1.52)$ & & \\
\hline \multirow[t]{2}{*}{ Exclude Top 25\% } & -0.86 & -0.43 & -0.34 & 99.21 & 3937 \\
\hline & $(-3.40)$ & $(-2.15)$ & $(-1.54)$ & & \\
\hline \multirow[t]{2}{*}{ Exclude Top 30\% } & -0.70 & -0.31 & -0.21 & 98.83 & 3674 \\
\hline & $(-2.85)$ & $(-1.58)$ & $(-0.98)$ & & \\
\hline \multirow[t]{2}{*}{ Exclude Top 35\% } & -0.68 & -0.26 & -0.19 & 98.32 & 3411 \\
\hline & $(-2.75)$ & $(-1.31)$ & $(-0.87)$ & & \\
\hline \multirow[t]{2}{*}{ Exclude Top 40\% } & -0.57 & -0.18 & -0.10 & 97.64 & 3149 \\
\hline & $(-2.42)$ & $(-0.93)$ & $(-0.50)$ & & \\
\hline \multirow[t]{2}{*}{ Exclude Top 45\% } & -0.53 & -0.15 & -0.08 & 96.75 & 2886 \\
\hline & $(-2.33)$ & $(-0.78)$ & $(-0.41)$ & & \\
\hline \multirow[t]{2}{*}{ Exclude Top 50\% } & -0.46 & -0.10 & -0.04 & 95.57 & 2624 \\
\hline & $(-2.09)$ & $(-0.52)$ & $(-0.22)$ & & \\
\hline \multirow[t]{2}{*}{ Exclude Top 55\% } & -0.39 & -0.03 & 0.02 & 94.01 & 2361 \\
\hline & $(-1.68)$ & $(-0.14)$ & $(0.07)$ & & \\
\hline \multirow[t]{2}{*}{ Exclude Top 60\% } & -0.37 & 0.01 & 0.04 & 92.03 & 2098 \\
\hline & $(-1.50)$ & $(0.03)$ & $(0.16)$ & & \\
\hline \multirow[t]{2}{*}{ Exclude Top 65\% } & -0.37 & -0.01 & 0.01 & 89.31 & 1835 \\
\hline & $(-1.56)$ & $(-0.04)$ & $(0.03)$ & & \\
\hline \multirow[t]{2}{*}{ Exclude Top 70\% } & -0.30 & 0.06 & 0.08 & 85.55 & 1573 \\
\hline & $(-1.29)$ & $(0.28)$ & $(0.33)$ & & \\
\hline \multirow[t]{2}{*}{ Exclude Top 75\% } & -0.30 & 0.07 & 0.07 & 80.35 & 1310 \\
\hline & $(-1.31)$ & $(0.32)$ & $(0.34)$ & & \\
\hline \multirow[t]{2}{*}{ Exclude Top 80\% } & -0.30 & 0.01 & 0.01 & 73.28 & 1047 \\
\hline & $(-1.33)$ & $(0.03)$ & $(0.06)$ & & \\
\hline \multirow[t]{2}{*}{ Exclude Top 85\% } & -0.26 & 0.09 & 0.09 & 63.41 & 784 \\
\hline & $(-1.11)$ & $(0.39)$ & $(0.38)$ & & \\
\hline \multirow[t]{2}{*}{ Exclude Top 90\% } & -0.33 & 0.02 & 0.01 & 49.89 & 522 \\
\hline & $(-1.44)$ & $(0.10)$ & $(0.05)$ & & \\
\hline Exclude Top 95\% & -0.36 & -0.14 & -0.19 & 30.17 & 260 \\
\hline
\end{tabular}




\section{Table 6}

Relation between maximum daily returns and subsequent trading behaviors.

This table shows the relation between maximum daily returns and subsequent trading behaviors. As outlined by Lee and Radhakrishna (2000), for each stock in each month, we partition trades into five bins according to trade size (dollar volume). Trades no more than $\$ 5,000$ (small trades) are used as a proxy for individual investor trades, while trades greater than \$50,000 (large trades) are used as a proxy for institutional trades. To account for changes in purchasing power over time, trade size bins are based on 1991 real dollars and adjusted using the Consumer Price Index. Then, we divide stocks into quintile groups based on the maximum daily return from the previous month. In Panel A, we report the average percentage of trading volume in each trade bin for stocks in the MAX quintiles in the month subsequent to the sorting. In Panel B, we report the average percentage of buy-initiated trading volume in each trade bin for stocks in the MAX quintiles in the month subsequent to the sorting. We infer each trade as buyer initiated following the procedure outlined in Lee and Ready (1991). The sample starts in 1993 and ends in 2000 due to data availability, the introduction of decimalization and growing use of computerized trading algorithms.

\begin{tabular}{|c|c|c|c|c|c|}
\hline & \multicolumn{5}{|c|}{ Maximum Daily Return Quintiles } \\
\hline & Low & 2 & 3 & 4 & High \\
\hline \multicolumn{6}{|l|}{ PANELA: Total Trades } \\
\hline $\mathrm{T}<=\$ 5,000$ (small trades) & $6.61 \%$ & $9.53 \%$ & $13.96 \%$ & $20.81 \%$ & $35.60 \%$ \\
\hline$\$ 5,000<T<=\$ 10,000$ & $8.17 \%$ & $10.26 \%$ & $13.14 \%$ & $16.11 \%$ & $18.80 \%$ \\
\hline$\$ 10,000<T<=\$ 20,000$ & $11.80 \%$ & $13.70 \%$ & $15.64 \%$ & $16.72 \%$ & $15.71 \%$ \\
\hline$\$ 20,000<T<=\$ 50,000$ & $17.56 \%$ & $18.34 \%$ & $18.64 \%$ & $17.55 \%$ & $13.49 \%$ \\
\hline$\$ 50,000<\mathrm{T}$ (large trades) & $55.85 \%$ & $48.17 \%$ & $38.62 \%$ & $28.81 \%$ & $16.40 \%$ \\
\hline \multicolumn{6}{|l|}{ PANEL B: Buy Trades } \\
\hline $\mathrm{T}<=\$ 5,000$ (small trades) & $6.94 \%$ & $9.88 \%$ & $14.34 \%$ & $21.25 \%$ & $36.12 \%$ \\
\hline$\$ 5,000<T<=\$ 10,000$ & $8.52 \%$ & $10.63 \%$ & $13.50 \%$ & $16.50 \%$ & $19.22 \%$ \\
\hline$\$ 10,000<T<=\$ 20,000$ & $12.09 \%$ & $13.99 \%$ & $15.87 \%$ & $16.91 \%$ & $15.86 \%$ \\
\hline$\$ 20,000<T<=\$ 50,000$ & $17.96 \%$ & $18.69 \%$ & $18.88 \%$ & $17.73 \%$ & $13.47 \%$ \\
\hline$\$ 50,000<T$ (large trades) & $54.48 \%$ & $46.81 \%$ & $37.40 \%$ & $27.62 \%$ & $15.33 \%$ \\
\hline
\end{tabular}


Table 7

Double sorts on individual preference index and skewness measures constructed under different horizons.

This table shows the value-weighted average returns to portfolios double sorted on the individual preference index and seven skewness measures, as well as the results of time series regressions of high-minus-low portfolio returns on Fama and French factors [market, size, value, RMW, CMA] and Carhart's momentum factor. Univariate sorting results based on each of these seven skewness measures are provided in the first row of every double sort. Newey-West adjusted test statistics are reported in brackets. All portfolios are sorted and rebalanced at month end based on whole sample breaks. Individual preference index is a composite rank based on ten stock characteristics preferred by individual investors. In Panel A, total skewness is the return skewness for each stock from the past six months. In Panel B, idiosyncratic skewness is the skewness of the residual obtained by fitting a two-factor model to the daily stock returns time series, where the two factors are the excess market returns and the squared excess market returns, as outlined by Harvey and Siddique (2000). Previous six months of daily returns are used to construct this measure. In Panel C, total skewness is the return skewness for each stock from the past twelve months. In Panel D, idiosyncratic skewness is also constructed following Harvey and Siddique but using daily returns from the previous twelve months. In Panel E, total skewness is the return skewness for each stock from the past sixty months. In Panel F, idiosyncratic skewness is the skewness of the residual obtained by fitting Fama and French three-factor model to the daily stock returns from the past sixty months. In Panel G, expected idiosyncratic skewness is estimated from a cross-sectional model on lagged skewness and firm characteristics, following Boyer, Mitton, and Vorkink (2010). The sample covers January 1976 to December 2014.

\begin{tabular}{|c|c|c|c|c|c|c|c|c|c|c|}
\hline \multicolumn{11}{|c|}{ PANEL A: Total Skewness (6m) } \\
\hline & \multicolumn{5}{|c|}{ TSKEW Quintiles } & \multicolumn{5}{|c|}{ High TSKEW - Low TSKEW } \\
\hline & Low & 2 & 3 & 4 & High & Raw & Alpha_3F & Alpha_4F & Alpha_5F & Alpha_6F \\
\hline \multicolumn{11}{|c|}{ Preference Index } \\
\hline All & 1.07 & 1.05 & 1.08 & 1.01 & 1.08 & $\begin{array}{c}0.01 \\
(0.04)\end{array}$ & $\begin{array}{c}-0.10 \\
(-0.80)\end{array}$ & $\begin{array}{c}-0.07 \\
(-0.55)\end{array}$ & $\begin{array}{c}0.04 \\
(0.34)\end{array}$ & $\begin{array}{c}0.05 \\
(0.38)\end{array}$ \\
\hline Low & 1.11 & 0.99 & 1.04 & 1.05 & 1.16 & $\begin{array}{c}0.04 \\
(0.37)\end{array}$ & $\begin{array}{c}-0.03 \\
(-0.24)\end{array}$ & $\begin{array}{c}-0.01 \\
(-0.10)\end{array}$ & $\begin{array}{c}-0.06 \\
(-0.46)\end{array}$ & $\begin{array}{c}-0.05 \\
(-0.35)\end{array}$ \\
\hline 2 & 0.94 & 1.04 & 1.20 & 1.00 & 1.17 & $\begin{array}{c}0.23 \\
(1.34)\end{array}$ & $\begin{array}{c}0.25 \\
(1.38)\end{array}$ & $\begin{array}{c}0.12 \\
(0.59)\end{array}$ & $\begin{array}{c}0.26 \\
(1.23)\end{array}$ & $\begin{array}{c}0.18 \\
(0.83)\end{array}$ \\
\hline 3 & 0.86 & 0.90 & 1.01 & 1.18 & 0.88 & $\begin{array}{c}0.02 \\
(0.11)\end{array}$ & $\begin{array}{c}0.07 \\
(0.35)\end{array}$ & $\begin{array}{c}-0.13 \\
(-0.64)\end{array}$ & $\begin{array}{c}0.16 \\
(0.75)\end{array}$ & $\begin{array}{c}0.02 \\
(0.07)\end{array}$ \\
\hline 4 & 0.58 & 1.02 & 0.88 & 0.87 & 0.56 & $\begin{array}{c}-0.01 \\
(-0.06)\end{array}$ & $\begin{array}{c}0.08 \\
(0.30)\end{array}$ & $\begin{array}{c}-0.20 \\
(-0.77)\end{array}$ & $\begin{array}{c}0.28 \\
(1.04)\end{array}$ & $\begin{array}{c}0.08 \\
(0.32)\end{array}$ \\
\hline High & 1.14 & 0.81 & 1.00 & 0.70 & 0.30 & $\begin{array}{c}-0.84 \\
(-2.99)\end{array}$ & $\begin{array}{c}-0.79 \\
(-2.87)\end{array}$ & $\begin{array}{c}-0.93 \\
(-3.28)\end{array}$ & $\begin{array}{c}-0.60 \\
(-1.99)\end{array}$ & $\begin{array}{c}-0.71 \\
(-2.44)\end{array}$ \\
\hline \multicolumn{11}{|c|}{ PANEL B: Idiosyncratic Skewness (6m) } \\
\hline & \multicolumn{5}{|c|}{ ISKEW Quintiles } & \multicolumn{5}{|c|}{ High ISKEW - Low ISKEW } \\
\hline & Low & 2 & 3 & 4 & High & Raw & Alpha_3F & Alpha_4F & Alpha_5F & Alpha_6F \\
\hline Prefere & Index & & & & & & & & & \\
\hline All & 1.10 & 1.04 & 1.14 & 1.01 & 1.06 & $\begin{array}{l}-0.05 \\
(-0.37)\end{array}$ & $\begin{array}{c}-0.18 \\
(-1.50)\end{array}$ & $\begin{array}{c}-0.24 \\
(-1.98)\end{array}$ & $\begin{array}{c}-0.05 \\
(-0.42)\end{array}$ & $\begin{array}{c}-0.11 \\
(-0.87)\end{array}$ \\
\hline Low & 1.15 & 1.02 & 1.14 & 1.02 & 1.03 & $\begin{array}{c}-0.12 \\
(-1.06)\end{array}$ & $\begin{array}{c}-0.20 \\
(-1.60)\end{array}$ & $\begin{array}{c}-0.30 \\
(-2.34)\end{array}$ & $\begin{array}{c}-0.22 \\
(-1.49)\end{array}$ & $\begin{array}{c}-0.28 \\
(-1.95)\end{array}$ \\
\hline 2 & 0.95 & 1.06 & 1.18 & 1.02 & 1.17 & $\begin{array}{c}0.22 \\
(1.55)\end{array}$ & $\begin{array}{c}0.20 \\
(1.27)\end{array}$ & $\begin{array}{c}-0.05 \\
(-0.28)\end{array}$ & $\begin{array}{c}0.14 \\
(0.68)\end{array}$ & $\begin{array}{c}-0.02 \\
(-0.09)\end{array}$ \\
\hline 3 & 0.78 & 1.05 & 0.86 & 1.11 & 1.05 & $\begin{array}{c}0.27 \\
(1.49)\end{array}$ & $\begin{array}{c}0.28 \\
(1.48)\end{array}$ & $\begin{array}{c}0.04 \\
(0.23)\end{array}$ & $\begin{array}{c}0.28 \\
(1.36)\end{array}$ & $\begin{array}{c}0.12 \\
(0.64)\end{array}$ \\
\hline 4 & 0.56 & 0.77 & 0.95 & 0.92 & 0.49 & $\begin{array}{c}-0.06 \\
(-0.28)\end{array}$ & $\begin{array}{c}-0.01 \\
(-0.06)\end{array}$ & $\begin{array}{c}-0.38 \\
(-1.61)\end{array}$ & $\begin{array}{c}0.17 \\
(0.68)\end{array}$ & $\begin{array}{c}-0.08 \\
(-0.38)\end{array}$ \\
\hline High & 1.15 & 0.86 & 0.99 & 0.62 & 0.31 & $\begin{array}{c}-0.84 \\
(-3.10)\end{array}$ & $\begin{array}{c}-0.73 \\
(-2.71)\end{array}$ & $\begin{array}{c}-0.96 \\
(-3.60)\end{array}$ & $\begin{array}{c}-0.59 \\
(-1.97)\end{array}$ & $\begin{array}{c}-0.75 \\
(-2.74)\end{array}$ \\
\hline
\end{tabular}




\begin{tabular}{|c|c|c|c|c|c|c|c|c|c|c|}
\hline \multicolumn{11}{|c|}{ PANEL C: Total Skewness (12m) } \\
\hline & \multicolumn{5}{|c|}{ TSKEW Quintiles } & \multicolumn{5}{|c|}{ High TSKEW - Low TSKEW } \\
\hline & Low & 2 & 3 & 4 & High & Raw & Alpha_3F & Alpha_4F & Alpha_5F & Alpha_6F \\
\hline \multicolumn{11}{|c|}{ Preference Index } \\
\hline \multirow[t]{2}{*}{ All } & 1.10 & 1.04 & 1.12 & 0.98 & 1.22 & 0.12 & -0.01 & -0.07 & 0.14 & 0.08 \\
\hline & & & & & & $(0.82)$ & $(-0.05)$ & $(-0.60)$ & $(1.07)$ & $(0.67)$ \\
\hline \multirow[t]{2}{*}{ Low } & 1.12 & 1.03 & 1.10 & 0.98 & 1.20 & 0.08 & 0.02 & -0.10 & 0.02 & -0.06 \\
\hline & & & & & & $(0.59)$ & $(0.15)$ & $(-0.81)$ & $(0.12)$ & $(-1.95)$ \\
\hline \multirow[t]{2}{*}{2} & 1.05 & 0.99 & 1.08 & 1.10 & 1.26 & 0.21 & 0.24 & 0.14 & 0.18 & 0.12 \\
\hline & & & & & & $(1.26)$ & (1.38) & $(0.69)$ & $(0.92)$ & $(-0.09)$ \\
\hline \multirow[t]{2}{*}{3} & 0.98 & 0.87 & 1.00 & 1.26 & 1.20 & 0.22 & 0.22 & -0.06 & 0.41 & 0.21 \\
\hline & & & & & & $(1.12)$ & $(1.07)$ & $(-0.29)$ & (1.94) & $(0.64)$ \\
\hline \multirow[t]{2}{*}{4} & 0.74 & 0.82 & 0.91 & 0.90 & 0.74 & 0.00 & 0.06 & -0.27 & 0.25 & 0.02 \\
\hline & & & & & & $(-0.01)$ & $(0.20)$ & $(-0.98)$ & $(0.91)$ & $(-0.38)$ \\
\hline \multirow[t]{2}{*}{ High } & 1.46 & 1.06 & 0.85 & 0.57 & 0.51 & -0.95 & -0.87 & -1.09 & -0.68 & -0.85 \\
\hline & & & & & & $(-3.38)$ & $(-3.10)$ & $(-3.90)$ & $(-2.24)$ & $(-2.74)$ \\
\hline \multicolumn{11}{|c|}{ PANEL D: Idiosyncratic Skewness (12m) } \\
\hline & \multicolumn{5}{|c|}{ ISKEW Quintiles } & \multicolumn{5}{|c|}{ High ISKEW - Low ISKEW } \\
\hline & Low & 2 & 3 & 4 & High & Raw & Alpha_3F & Alpha_4F & Alpha_5F & Alpha_6F \\
\hline \multicolumn{11}{|c|}{ Preference Index } \\
\hline \multirow[t]{2}{*}{ All } & 1.05 & 1.07 & 1.18 & 1.08 & 1.22 & 0.17 & 0.00 & -0.13 & 0.14 & 0.04 \\
\hline & & & & & & $(1.20)$ & $(0.00)$ & $(-0.99)$ & (0.95) & $(0.31)$ \\
\hline \multirow[t]{2}{*}{ Low } & 1.08 & 1.09 & 1.11 & 1.04 & 1.21 & 0.13 & 0.01 & -0.17 & 0.05 & -0.07 \\
\hline & & & & & & $(0.92)$ & $(0.07)$ & $(-1.31)$ & $(0.31)$ & $(-0.50)$ \\
\hline \multirow[t]{2}{*}{2} & 1.01 & 1.03 & 1.13 & 1.08 & 1.20 & 0.19 & 0.13 & -0.11 & 0.06 & -0.10 \\
\hline & & & & & & (1.19) & $(0.73)$ & $(-0.55)$ & $(0.27)$ & $(-0.46)$ \\
\hline \multirow[t]{2}{*}{3} & 0.80 & 1.03 & 0.93 & 1.31 & 1.24 & 0.44 & 0.38 & 0.06 & 0.49 & 0.27 \\
\hline & & & & & & (2.24) & (1.83) & $(0.31)$ & (2.17) & (1.42) \\
\hline \multirow[t]{2}{*}{4} & 0.57 & 0.73 & 1.18 & 0.76 & 0.71 & 0.14 & 0.23 & -0.18 & 0.35 & 0.07 \\
\hline & & & & & & $(0.54)$ & $(0.82)$ & $(-0.66)$ & (1.19) & $(0.28)$ \\
\hline \multirow[t]{2}{*}{ High } & 1.46 & 1.02 & 0.96 & 0.55 & 0.44 & -1.01 & -0.86 & -1.24 & -0.80 & -1.06 \\
\hline & & & & & & $(-3.31)$ & $(-2.88)$ & $(-4.28)$ & $(-2.33)$ & $(-3.46)$ \\
\hline PANEL & Total S & ness ( & & & & & & & & \\
\hline & & & W Qu & & & & High & SKEW - Lo & TSKEW & \\
\hline & Low & 2 & 3 & 4 & High & Raw & Alpha_3F & Alpha_4F & Alpha_5F & Alpha_6F \\
\hline Prefere & Index & & & & & & & & & \\
\hline All & 1.08 & 1.06 & 1.11 & 1.20 & 1.14 & 0.06 & -0.12 & -0.13 & 0.07 & 0.04 \\
\hline & & & & & & $(0.40)$ & $(-0.98)$ & $(-1.03)$ & (0.49) & (0.33) \\
\hline Low & 1.09 & 1.03 & 1.09 & 1.12 & 1.21 & 0.12 & 0.05 & -0.04 & 0.11 & 0.04 \\
\hline & & & & & & $(0.72)$ & $(0.31)$ & $(-0.26)$ & $(0.54)$ & $(0.23)$ \\
\hline 2 & 1.03 & 1.18 & 1.21 & 1.09 & 1.33 & 0.30 & 0.31 & 0.06 & 0.15 & 0.00 \\
\hline & & & & & & (1.61) & (1.56) & $(0.28)$ & (0.66) & $(0.02)$ \\
\hline 3 & 1.13 & 1.01 & 1.28 & 1.24 & 0.95 & -0.19 & -0.12 & -0.36 & -0.07 & -0.23 \\
\hline & & & & & & $(-0.93)$ & $(-0.57)$ & $(-1.75)$ & $(-0.31)$ & $(-1.08)$ \\
\hline 4 & 1.35 & 1.17 & 0.96 & 1.27 & 0.89 & -0.46 & -0.42 & -0.62 & -0.10 & -0.27 \\
\hline & & & & & & $(-1.91)$ & $(-1.62)$ & $(-2.37)$ & $(-0.41)$ & $(-1.06)$ \\
\hline High & 1.63 & 1.34 & 1.34 & 1.13 & 0.77 & -0.87 & -0.75 & -0.99 & -0.66 & -0.83 \\
\hline & & & & & & $(-2.44)$ & $(-1.93)$ & $(-2.51)$ & $(-1.63)$ & $(-2.07)$ \\
\hline
\end{tabular}




\begin{tabular}{|c|c|c|c|c|c|c|c|c|c|c|}
\hline \multicolumn{11}{|c|}{ PANEL F: Idiosyncratic Skewness (60m) } \\
\hline & \multicolumn{5}{|c|}{ ISKEW Quintiles } & \multicolumn{5}{|c|}{ High ISKEW - Low ISKEW } \\
\hline & Low & 2 & 3 & 4 & High & Raw & Alpha_3F & Alpha_4F & Alpha_5F & Alpha_6F \\
\hline \multicolumn{11}{|c|}{ Preference Index } \\
\hline All & 1.01 & 1.07 & 1.23 & 1.22 & 1.13 & $\begin{array}{c}0.11 \\
(0.83)\end{array}$ & $\begin{array}{c}-0.09 \\
(-0.76)\end{array}$ & $\begin{array}{c}-0.14 \\
(-1.06)\end{array}$ & $\begin{array}{c}0.04 \\
(0.31)\end{array}$ & $\begin{array}{c}-0.01 \\
(-0.06)\end{array}$ \\
\hline Low & 1.01 & 1.04 & 1.27 & 1.22 & 1.08 & $\begin{array}{c}0.07 \\
(0.54)\end{array}$ & $\begin{array}{c}0.00 \\
(0.01)\end{array}$ & $\begin{array}{c}-0.12 \\
(-0.83)\end{array}$ & $\begin{array}{c}0.04 \\
(0.27)\end{array}$ & $\begin{array}{c}-0.05 \\
(-0.32)\end{array}$ \\
\hline 2 & 1.05 & 1.16 & 1.12 & 1.11 & 1.25 & $\begin{array}{c}0.20 \\
(1.22)\end{array}$ & $\begin{array}{c}0.20 \\
(1.14)\end{array}$ & $\begin{array}{c}-0.08 \\
(-0.39)\end{array}$ & $\begin{array}{c}0.02 \\
(0.09)\end{array}$ & $\begin{array}{c}-0.15 \\
(-0.68)\end{array}$ \\
\hline 3 & 1.08 & 1.10 & 1.19 & 1.22 & 1.06 & $\begin{array}{c}-0.02 \\
(-0.11)\end{array}$ & $\begin{array}{c}-0.02 \\
(-0.08)\end{array}$ & $\begin{array}{c}-0.25 \\
(-1.27)\end{array}$ & $\begin{array}{c}0.01 \\
(0.04)\end{array}$ & $\begin{array}{c}-0.15 \\
(-0.73)\end{array}$ \\
\hline 4 & 1.29 & 0.99 & 1.10 & 1.16 & 0.97 & $\begin{array}{c}-0.33 \\
(-1.37)\end{array}$ & $\begin{array}{c}-0.30 \\
(-1.16)\end{array}$ & $\begin{array}{c}-0.54 \\
(-2.01)\end{array}$ & $\begin{array}{c}-0.04 \\
(-0.17)\end{array}$ & $\begin{array}{c}-0.23 \\
(-0.86)\end{array}$ \\
\hline High & 1.35 & 1.66 & 1.24 & 1.09 & 0.73 & $\begin{array}{c}-0.62 \\
(-1.80)\end{array}$ & $\begin{array}{c}-0.51 \\
(-1.44)\end{array}$ & $\begin{array}{c}-0.77 \\
(-2.12)\end{array}$ & $\begin{array}{c}-0.49 \\
(-1.25)\end{array}$ & $\begin{array}{c}-0.66 \\
(-1.74)\end{array}$ \\
\hline \multicolumn{11}{|c|}{ PANEL G: Expected Idiosyncratic Skewness (60m) } \\
\hline & \multicolumn{5}{|c|}{ EISKEW Quintiles } & \multicolumn{5}{|c|}{ High EISKEW - Low EISKEW } \\
\hline & Low & 2 & 3 & 4 & High & Raw & Alpha_3F & Alpha_4F & Alpha_5F & Alpha_6F \\
\hline \multicolumn{11}{|c|}{ Preference Index } \\
\hline All & 1.22 & 1.13 & 1.07 & 1.05 & 0.77 & $\begin{array}{c}-0.46 \\
(-1.47)\end{array}$ & $\begin{array}{c}-0.63 \\
(-1.69)\end{array}$ & $\begin{array}{c}-0.42 \\
(-1.36)\end{array}$ & $\begin{array}{c}-0.29 \\
(-1.02)\end{array}$ & $\begin{array}{c}-0.26 \\
(-0.98)\end{array}$ \\
\hline Low & 1.08 & 0.95 & 1.12 & 0.97 & 1.12 & $\begin{array}{c}0.11 \\
(0.33)\end{array}$ & $\begin{array}{c}-0.14 \\
(-0.45)\end{array}$ & $\begin{array}{c}-0.08 \\
(-0.25)\end{array}$ & $\begin{array}{c}-0.05 \\
(-0.16)\end{array}$ & $\begin{array}{c}-0.02 \\
(-0.07)\end{array}$ \\
\hline 2 & 1.11 & 1.12 & 0.97 & 1.57 & 1.25 & $\begin{array}{c}0.14 \\
(0.56)\end{array}$ & $\begin{array}{c}-0.03 \\
(-0.11)\end{array}$ & $\begin{array}{c}-0.14 \\
(-0.53)\end{array}$ & $\begin{array}{c}-0.18 \\
(-0.69)\end{array}$ & $\begin{array}{c}-0.24 \\
(-0.90)\end{array}$ \\
\hline 3 & 1.23 & 1.09 & 1.34 & 0.84 & 1.06 & $\begin{array}{c}-0.17 \\
(-0.61)\end{array}$ & $\begin{array}{c}-0.18 \\
(-0.58)\end{array}$ & $\begin{array}{c}-0.03 \\
(-0.09)\end{array}$ & $\begin{array}{c}-0.33 \\
(-1.08)\end{array}$ & $\begin{array}{c}-0.21 \\
(-0.70)\end{array}$ \\
\hline 4 & 0.76 & 1.24 & 1.31 & 1.35 & 0.93 & $\begin{array}{c}0.15 \\
(0.25)\end{array}$ & $\begin{array}{c}0.54 \\
(0.92)\end{array}$ & $\begin{array}{c}0.54 \\
(0.88)\end{array}$ & $\begin{array}{c}0.71 \\
(1.20)\end{array}$ & $\begin{array}{c}0.69 \\
(1.13)\end{array}$ \\
\hline High & 1.59 & 1.24 & 1.01 & 1.25 & 0.96 & $\begin{array}{c}-0.63 \\
(-1.91)\end{array}$ & $\begin{array}{c}-0.72 \\
(-2.17)\end{array}$ & $\begin{array}{c}-0.78 \\
(-2.09)\end{array}$ & $\begin{array}{c}-0.68 \\
(-1.83)\end{array}$ & $\begin{array}{c}-0.54 \\
(-1.74)\end{array}$ \\
\hline
\end{tabular}


Table 8

Fama and MacBeth regressions of returns on the interactions of skewness and individual preference index and control variables

This table shows average slopes and their Newey-West adjusted t-statistics from monthly cross-section regressions to predict stock returns. We consider the interaction of skewness and the individual preference index. Individual preference index is a composite rank based on ten stock characteristics preferred by individual investors. I (port=Low) is a dummy variable that equals one if the stock is in the bottom quintile of the index, I (port=High) is a dummy variable that equals one if the stock is in the top quintile of the index, I (port=2), I (port=3), I $($ port $=4$ ) are defined accordingly. Total skewness (TSKEW) is the return skewness for each stock from the past 6/12/60 months. Idiosyncratic skewness (ISKEW) is the skewness of the residual obtained by fitting factor models to the daily returns from the past 6/12/60 months Expected idiosyncratic skewness is estimated from a cross-sectional model following Boyer, Mitton, and Vorkink (2010).

\begin{tabular}{|c|c|c|c|c|c|c|c|}
\hline $\begin{array}{c}\text { Independent } \\
\text { Variable } \\
\end{array}$ & $\begin{array}{c}\text { TSKEW } \\
(6 \mathrm{~m})\end{array}$ & $\begin{array}{c}\text { ISKEW } \\
(6 \mathrm{~m})\end{array}$ & $\begin{array}{c}\text { TSKEW } \\
(12 \mathrm{~m})\end{array}$ & $\begin{array}{c}\text { ISKEW } \\
(12 \mathrm{~m})\end{array}$ & $\begin{array}{c}\text { TSKEW } \\
(60 \mathrm{~m})\end{array}$ & $\begin{array}{c}\text { ISKEW } \\
(60 \mathrm{~m})\end{array}$ & $\begin{array}{c}\text { EISKEW } \\
(60 \mathrm{~m})\end{array}$ \\
\hline \multirow[t]{2}{*}{ Skew*I(port=1) } & 0.083 & 0.050 & 0.059 & 0.027 & 0.005 & 0.033 & 0.120 \\
\hline & (2.58) & $(1.60)$ & (1.65) & $(0.83)$ & $(0.11)$ & $(0.87)$ & $(1.30)$ \\
\hline \multirow[t]{2}{*}{ Skew*I(port=2) } & 0.067 & 0.059 & 0.003 & -0.001 & -0.043 & -0.042 & -0.024 \\
\hline & (2.06) & $(2.00)$ & $(0.08)$ & $(-0.04)$ & $(-1.13)$ & $(-1.17)$ & $(-0.21)$ \\
\hline \multirow[t]{2}{*}{ Skew*I(port=3) } & 0.075 & 0.077 & -0.001 & 0.001 & -0.055 & -0.052 & -0.001 \\
\hline & $(2.30)$ & (2.39) & $(-0.02)$ & $(0.02)$ & $(-1.71)$ & $(-1.68)$ & $(-0.01)$ \\
\hline \multirow[t]{2}{*}{ Skew*I(port=4) } & -0.025 & -0.039 & -0.114 & -0.118 & -0.142 & -0.139 & -0.136 \\
\hline & $(-0.73)$ & $(-1.17)$ & $(-3.32)$ & $(-3.56)$ & $(-4.29)$ & $(-4.35)$ & $(-1.97)$ \\
\hline \multirow[t]{2}{*}{ Skew*I(port=5) } & -0.164 & -0.156 & -0.201 & -0.189 & -0.151 & -0.146 & -0.218 \\
\hline & $(-3.41)$ & $(-3.23)$ & $(-4.58)$ & $(-4.35)$ & $(-3.83)$ & $(-3.78)$ & $(-2.87)$ \\
\hline \multirow[t]{2}{*}{ Preference Index } & -0.014 & -0.014 & -0.013 & -0.013 & -0.008 & -0.008 & -0.004 \\
\hline & $(-2.75)$ & $(-2.73)$ & $(-2.66)$ & $(-2.65)$ & $(-1.81)$ & $(-1.73)$ & $(-0.73)$ \\
\hline \multirow[t]{2}{*}{ Beta } & 0.024 & 0.024 & 0.021 & 0.021 & 0.007 & 0.007 & 0.011 \\
\hline & $(0.72)$ & $(0.71)$ & $(0.64)$ & $(0.63)$ & $(0.21)$ & $(0.21)$ & $(0.32)$ \\
\hline \multirow[t]{2}{*}{ Size } & -0.220 & -0.220 & -0.223 & -0.223 & -0.200 & -0.197 & -0.187 \\
\hline & $(-6.82)$ & $(-6.83)$ & $(-6.88)$ & $(-6.86)$ & $(-6.39)$ & $(-6.30)$ & $(-5.64)$ \\
\hline \multirow[t]{2}{*}{ Beme } & 0.548 & 0.548 & 0.546 & 0.545 & 0.429 & 0.428 & 0.439 \\
\hline & (6.11) & (6.11) & (6.07) & $(6.07)$ & (5.14) & (5.13) & (5.22) \\
\hline \multirow[t]{2}{*}{ Mom } & 0.007 & 0.007 & 0.007 & 0.007 & 0.007 & 0.006 & 0.006 \\
\hline & $(4.44)$ & $(4.46)$ & $(4.65)$ & $(4.66)$ & $(4.32)$ & $(4.28)$ & (3.89) \\
\hline \multirow[t]{2}{*}{ Strev } & -0.049 & -0.049 & -0.048 & -0.048 & -0.052 & -0.052 & -0.055 \\
\hline & $(-11.82)$ & $(-11.82)$ & $(-11.61)$ & $(-11.60)$ & $(-13.02)$ & $(-13.01)$ & $(-13.78)$ \\
\hline \multirow[t]{2}{*}{ Illiq } & 0.021 & 0.021 & 0.021 & 0.021 & 0.017 & 0.017 & 0.019 \\
\hline & (3.60) & (3.57) & (3.54) & (3.54) & (3.16) & (3.12) & (3.67) \\
\hline \multirow[t]{2}{*}{ Ivol } & -0.212 & -0.213 & -0.202 & -0.204 & -0.201 & -0.202 & -0.190 \\
\hline & $(-4.26)$ & $(-4.29)$ & $(-4.22)$ & $(-4.27)$ & $(-4.21)$ & $(-4.25)$ & $(-4.03)$ \\
\hline \multirow[t]{2}{*}{ Coskew } & -0.182 & -0.177 & -0.149 & -0.172 & -0.090 & -0.093 & -0.050 \\
\hline & $(-0.89)$ & $(-0.86)$ & $(-0.73)$ & $(-0.84)$ & $(-0.41)$ & $(-0.42)$ & $(-0.22)$ \\
\hline \multirow[t]{2}{*}{ NS } & -0.028 & -0.028 & -0.028 & -0.028 & -0.032 & -0.032 & -0.033 \\
\hline & $(-4.55)$ & $(-4.54)$ & $(-4.40)$ & $(-4.41)$ & $(-4.83)$ & $(-4.86)$ & $(-4.87)$ \\
\hline \multirow[t]{2}{*}{ Assetg } & 0.010 & 0.010 & 0.010 & 0.010 & 0.014 & 0.014 & 0.014 \\
\hline & $(2.90)$ & $(2.92)$ & $(2.76)$ & $(2.78)$ & (3.16) & (3.16) & (3.13) \\
\hline \multirow[t]{2}{*}{ Accruals } & -0.020 & -0.020 & -0.020 & -0.020 & -0.024 & -0.024 & -0.027 \\
\hline & $(-5.61)$ & $(-5.61)$ & $(-5.53)$ & $(-5.53)$ & $(-6.19)$ & $(-6.18)$ & $(-6.71)$ \\
\hline \multirow[t]{2}{*}{ Turnover } & 0.442 & 0.445 & 0.428 & 0.426 & 0.401 & 0.401 & 0.387 \\
\hline & (3.24) & (3.26) & (3.14) & (3.12) & $(2.75)$ & $(2.76)$ & (2.58) \\
\hline
\end{tabular}




\section{Table 9}

Double sorts on individual preference index and average high daily returns.

This table shows the value-weighted average returns to portfolios double sorted on the individual preference index and four alternative MAX measures, as well as the results of time series regressions of high-minus-low portfolio returns on Fama and French factors [market, size, value, RMW, CMA] and Carhart's momentum factor. Univariate sorting results based on each of these alternative MAX measures are provided in the first row of each double sort. Newey-West adjusted test statistics are reported in brackets. All portfolios are sorted and rebalanced at month end based on whole sample breaks. Individual preference index is a composite rank based on ten stock characteristics preferred by individual investors. In Panel A, MAX(2) is the average top two daily returns over the past month. In Panel B, MAX(3) is the average top three daily returns over the past month. In Panel C, MAX(4) is the average top four daily returns over the past month. In Panel D, MAX(5) is the average top five daily returns over the past month. The sample covers January 1976 to December 2014.

\begin{tabular}{|c|c|c|c|c|c|c|c|c|c|c|}
\hline \multicolumn{11}{|c|}{ PANEL A: MAX(2) } \\
\hline & \multicolumn{5}{|c|}{ MAX(2) Quintiles } & \multicolumn{5}{|c|}{ High $\operatorname{MAX}(2)$ - Low MAX(2) } \\
\hline & Low & 2 & 3 & 4 & High & Raw & Alpha_3F & Alpha_4F & Alpha_5F & Alpha_6F \\
\hline \multicolumn{11}{|c|}{ Preference Index } \\
\hline All & 1.08 & 1.13 & 1.12 & 1.01 & 0.41 & $\begin{array}{c}-0.67 \\
(-1.92)\end{array}$ & $\begin{array}{c}-1.16 \\
(-5.28)\end{array}$ & $\begin{array}{c}-0.92 \\
(-3.77)\end{array}$ & $\begin{array}{c}-0.47 \\
(-2.48)\end{array}$ & $\begin{array}{c}-0.38 \\
(-1.83)\end{array}$ \\
\hline Low & 1.07 & 1.10 & 1.08 & 1.16 & 1.33 & $\begin{array}{c}0.28 \\
(0.73)\end{array}$ & $\begin{array}{c}0.13 \\
(0.44)\end{array}$ & $\begin{array}{c}0.33 \\
(0.90)\end{array}$ & $\begin{array}{c}0.60 \\
(1.91)\end{array}$ & $\begin{array}{c}0.68 \\
(1.89)\end{array}$ \\
\hline 2 & 1.30 & 1.26 & 1.18 & 0.90 & 0.82 & $\begin{array}{c}-0.48 \\
(-1.41)\end{array}$ & $\begin{array}{c}-0.66 \\
(-2.52)\end{array}$ & $\begin{array}{c}-0.65 \\
(-2.25)\end{array}$ & $\begin{array}{c}-0.24 \\
(-0.96)\end{array}$ & $\begin{array}{c}-0.27 \\
(-1.03)\end{array}$ \\
\hline 3 & 1.34 & 1.33 & 1.14 & 0.93 & 0.11 & $\begin{array}{l}-1.23 \\
(-3.46)\end{array}$ & $\begin{array}{c}-1.51 \\
(-5.42)\end{array}$ & $\begin{array}{l}-1.39 \\
(-4.66)\end{array}$ & $\begin{array}{c}-0.84 \\
(-3.34)\end{array}$ & $\begin{array}{c}-0.83 \\
(-3.13)\end{array}$ \\
\hline 4 & 1.38 & 1.68 & 1.39 & 0.85 & -0.06 & $\begin{array}{c}-1.44 \\
(-4.56)\end{array}$ & $\begin{array}{c}-1.84 \\
(-7.70)\end{array}$ & $\begin{array}{l}-1.60 \\
(-6.33)\end{array}$ & $\begin{array}{c}-1.21 \\
(-5.61)\end{array}$ & $\begin{array}{c}-1.11 \\
(-4.99)\end{array}$ \\
\hline High & 1.38 & 1.73 & 1.60 & 1.18 & -0.04 & $\begin{array}{c}-1.46 \\
(-4.24)\end{array}$ & $\begin{array}{c}-1.86 \\
(-6.08)\end{array}$ & $\begin{array}{c}-1.62 \\
(-4.84)\end{array}$ & $\begin{array}{c}-1.34 \\
(-4.33)\end{array}$ & $\begin{array}{c}-1.23 \\
(-3.77)\end{array}$ \\
\hline \multicolumn{11}{|c|}{ PANEL B: MAX(3) } \\
\hline & \multicolumn{5}{|c|}{ MAX(3) Quintiles } & \multicolumn{5}{|c|}{ High MAX(3) - Low MAX(3) } \\
\hline & Low & 2 & 3 & 4 & High & Raw & Alpha_3F & Alpha_4F & Alpha_5F & Alpha_6F \\
\hline \multicolumn{11}{|c|}{ Preference Index } \\
\hline All & 1.09 & 1.13 & 1.12 & 0.94 & 0.41 & $\begin{array}{c}-0.67 \\
(-1.85)\end{array}$ & $\begin{array}{c}-1.20 \\
(-5.26)\end{array}$ & $\begin{array}{c}-0.96 \\
(-3.91)\end{array}$ & $\begin{array}{c}-0.48 \\
(-2.43)\end{array}$ & $\begin{array}{c}-0.39 \\
(-1.87)\end{array}$ \\
\hline Low & 1.08 & 1.10 & 1.05 & 1.02 & 1.16 & $\begin{array}{c}0.10 \\
(0.25)\end{array}$ & $\begin{array}{l}-0.04 \\
(-0.12)\end{array}$ & $\begin{array}{c}-0.06 \\
(-0.17)\end{array}$ & $\begin{array}{c}0.44 \\
(1.27)\end{array}$ & $\begin{array}{c}0.38 \\
(1.06)\end{array}$ \\
\hline 2 & 1.28 & 1.24 & 1.22 & 0.91 & 0.75 & $\begin{array}{c}-0.53 \\
(-1.48)\end{array}$ & $\begin{array}{c}-0.74 \\
(-2.80)\end{array}$ & $\begin{array}{c}-0.77 \\
(-2.64)\end{array}$ & $\begin{array}{c}-0.32 \\
(-1.24)\end{array}$ & $\begin{array}{c}-0.38 \\
(-1.39)\end{array}$ \\
\hline 3 & 1.28 & 1.33 & 1.25 & 0.91 & 0.06 & $\begin{array}{c}-1.21 \\
(-3.31)\end{array}$ & $\begin{array}{c}-1.53 \\
(-5.31)\end{array}$ & $\begin{array}{l}-1.37 \\
(-4.52)\end{array}$ & $\begin{array}{c}-0.81 \\
(-3.11)\end{array}$ & $\begin{array}{c}-0.78 \\
(-2.86)\end{array}$ \\
\hline 4 & 1.34 & 1.73 & 1.54 & 0.80 & -0.05 & $\begin{array}{l}-1.40 \\
(-4.23)\end{array}$ & $\begin{array}{c}-1.79 \\
(-6.94)\end{array}$ & $\begin{array}{c}-1.56 \\
(-5.91)\end{array}$ & $\begin{array}{c}-1.14 \\
(-5.15)\end{array}$ & $\begin{array}{c}-1.05 \\
(-4.61)\end{array}$ \\
\hline High & 1.53 & 1.69 & 1.71 & 1.19 & -0.04 & $\begin{array}{c}-1.57 \\
(-4.78)\end{array}$ & $\begin{array}{l}-1.85 \\
(-6.56)\end{array}$ & $\begin{array}{c}-1.80 \\
(-5.28)\end{array}$ & $\begin{array}{c}-1.51 \\
(-4.82)\end{array}$ & $\begin{array}{c}-1.41 \\
(-4.25)\end{array}$ \\
\hline
\end{tabular}




\begin{tabular}{|c|c|c|c|c|c|c|c|c|c|c|}
\hline \multicolumn{11}{|c|}{ PANEL C: MAX(4) } \\
\hline & \multicolumn{5}{|c|}{ MAX(4) Quintiles } & \multicolumn{5}{|c|}{ High MAX(4) - Low MAX(4) } \\
\hline & Low & 2 & 3 & 4 & High & Raw & Alpha_3F & Alpha_4F & Alpha_5F & Alpha_6F \\
\hline \multicolumn{11}{|c|}{ Preference Index } \\
\hline All & 1.10 & 1.11 & 1.13 & 0.97 & 0.41 & $\begin{array}{c}-0.69 \\
(-1.90)\end{array}$ & $\begin{array}{l}-1.22 \\
(-5.26)\end{array}$ & $\begin{array}{c}-0.98 \\
(-3.93)\end{array}$ & $\begin{array}{l}-0.48 \\
(-2.44)\end{array}$ & $\begin{array}{l}-0.40 \\
(-1.88)\end{array}$ \\
\hline Low & 1.09 & 1.08 & 1.05 & 1.10 & 1.05 & $\begin{array}{c}-0.03 \\
(-0.08)\end{array}$ & $\begin{array}{c}-0.22 \\
(-0.64)\end{array}$ & $\begin{array}{c}-0.21 \\
(-0.57)\end{array}$ & $\begin{array}{c}0.26 \\
(0.73)\end{array}$ & $\begin{array}{c}0.21 \\
(0.56)\end{array}$ \\
\hline 2 & 1.29 & 1.22 & 1.22 & 0.93 & 0.83 & $\begin{array}{c}-0.47 \\
(-1.31)\end{array}$ & $\begin{array}{c}-0.64 \\
(-2.34)\end{array}$ & $\begin{array}{c}-0.65 \\
(-2.20)\end{array}$ & $\begin{array}{c}-0.20 \\
(-0.74)\end{array}$ & $\begin{array}{c}-0.25 \\
(-0.89)\end{array}$ \\
\hline 3 & 1.26 & 1.35 & 1.36 & 0.86 & 0.06 & $\begin{array}{c}-1.20 \\
(-3.31)\end{array}$ & $\begin{array}{c}-1.50 \\
(-5.35)\end{array}$ & $\begin{array}{c}-1.34 \\
(-4.56)\end{array}$ & $\begin{array}{c}-0.77 \\
(-3.11)\end{array}$ & $\begin{array}{c}-0.74 \\
(-2.85)\end{array}$ \\
\hline 4 & 1.39 & 1.55 & 1.61 & 0.84 & -0.06 & $\begin{array}{c}-1.44 \\
(-4.37)\end{array}$ & $\begin{array}{c}-1.87 \\
(-7.14)\end{array}$ & $\begin{array}{l}-1.63 \\
(-6.1)\end{array}$ & $\begin{array}{c}-1.18 \\
(-5.33)\end{array}$ & $\begin{array}{c}-1.08 \\
(-4.74)\end{array}$ \\
\hline High & 1.45 & 1.81 & 1.73 & 1.07 & -0.04 & $\begin{array}{c}-1.49 \\
(-4.70) \\
\end{array}$ & $\begin{array}{c}-1.97 \\
(-6.66) \\
\end{array}$ & $\begin{array}{c}-1.70 \\
(-5.07) \\
\end{array}$ & $\begin{array}{c}-1.50 \\
(-4.95) \\
\end{array}$ & $\begin{array}{c}-1.37 \\
(-4.21) \\
\end{array}$ \\
\hline \multicolumn{11}{|c|}{ PANEL D: MAX(5) } \\
\hline & \multicolumn{5}{|c|}{ MAX(5) Quintiles } & \multicolumn{5}{|c|}{ High MAX(5) - Low MAX(5) } \\
\hline & Low & 2 & 3 & 4 & High & Raw & Alpha_3F & Alpha_4F & Alpha_5F & Alpha_6F \\
\hline \multicolumn{11}{|c|}{ Preference Index } \\
\hline All & 1.12 & 1.11 & 1.09 & 0.98 & 0.41 & $\begin{array}{l}-0.71 \\
(-1.95)\end{array}$ & $\begin{array}{l}-1.24 \\
(-5.33)\end{array}$ & $\begin{array}{l}-1.01 \\
(-3.97)\end{array}$ & $\begin{array}{l}-0.50 \\
(-2.52)\end{array}$ & $\begin{array}{l}-0.42 \\
(-1.94)\end{array}$ \\
\hline Low & 1.12 & 1.08 & 1.02 & 1.16 & 0.95 & $\begin{array}{c}-0.14 \\
(-0.35)\end{array}$ & $\begin{array}{c}-0.27 \\
(-0.81)\end{array}$ & $\begin{array}{c}-0.28 \\
(-0.78)\end{array}$ & $\begin{array}{c}0.20 \\
(0.58)\end{array}$ & $\begin{array}{c}0.14 \\
(0.37)\end{array}$ \\
\hline 2 & 1.32 & 1.24 & 1.20 & 0.93 & 0.72 & $\begin{array}{c}-0.60 \\
(-1.67)\end{array}$ & $\begin{array}{c}-0.78 \\
(-2.70)\end{array}$ & $\begin{array}{c}-0.81 \\
(-2.59)\end{array}$ & $\begin{array}{c}-0.29 \\
(-1.02)\end{array}$ & $\begin{array}{c}-0.36 \\
(-1.22)\end{array}$ \\
\hline 3 & 1.29 & 1.30 & 1.42 & 0.83 & 0.10 & $\begin{array}{c}-1.19 \\
(-3.24)\end{array}$ & $\begin{array}{c}-1.50 \\
(-5.27)\end{array}$ & $\begin{array}{c}-1.33 \\
(-4.36)\end{array}$ & $\begin{array}{c}-0.77 \\
(-3.05)\end{array}$ & $\begin{array}{c}-0.73 \\
(-2.71)\end{array}$ \\
\hline 4 & 1.33 & 1.65 & 1.54 & 0.85 & -0.04 & $\begin{array}{c}-1.37 \\
(-4.16)\end{array}$ & $\begin{array}{c}-1.81 \\
(-6.92)\end{array}$ & $\begin{array}{c}-1.57 \\
(-5.87)\end{array}$ & $\begin{array}{c}-1.15 \\
(-5.14)\end{array}$ & $\begin{array}{c}-1.05 \\
(-4.55)\end{array}$ \\
\hline High & 1.49 & 1.76 & 1.85 & 1.07 & -0.05 & $\begin{array}{c}-1.54 \\
(-4.78)\end{array}$ & $\begin{array}{l}-2.01 \\
(-6.65)\end{array}$ & $\begin{array}{c}-1.78 \\
(-5.30)\end{array}$ & $\begin{array}{c}-1.61 \\
(-5.42)\end{array}$ & $\begin{array}{l}-1.49 \\
(-4.73)\end{array}$ \\
\hline
\end{tabular}




\section{Table 10}

Fama and MacBeth regressions of returns on the interactions of average high daily returns and preference index and control variables.

This table shows average slopes and their Newey-West adjusted t-statistics from monthly cross-section regressions to predict stock returns. We consider the interaction of average high daily returns and the individual preference index. Individual preference index is a composite rank based on ten stock characteristics preferred by individual investors and covers 1976-2014. I (port=Low) is a dummy variable that equals one if the stock is in the bottom quintile of the index, I (port=High) is a dummy variable that equals one if the stock is in the top quintile of the index, I (port=2), I (port=3), I (port=4) are defined accordingly. MAX(2) is the average top two daily returns from the previous month, $\operatorname{MAX}(3)$ is the average top three daily returns from the previous month, $\operatorname{MAX}(4)$ is the average top four daily returns from the previous month, $\operatorname{MAX}(5)$ is the average top five daily returns from the previous month. Detailed information on other control variables can be found in the appendix.

\begin{tabular}{|c|c|c|c|c|}
\hline Independent Variable & MAX(2) & MAX(3) & $\operatorname{MAX}(4)$ & MAX(5) \\
\hline \multirow[t]{2}{*}{ MAX(N)*I(port=1) } & 0.007 & -0.002 & -0.009 & -0.012 \\
\hline & $(0.46)$ & $(-0.10)$ & $(-0.36)$ & $(-0.40)$ \\
\hline \multirow[t]{2}{*}{ MAX(N)*I(port=2) } & 0.007 & -0.001 & -0.006 & -0.008 \\
\hline & $(0.57)$ & $(-0.06)$ & $(-0.31)$ & $(-0.34)$ \\
\hline \multirow[t]{2}{*}{$\operatorname{MAX}(\mathbf{N}) * I($ port=3) } & -0.006 & -0.017 & -0.025 & -0.030 \\
\hline & $(-0.64)$ & $(-1.30)$ & $(-1.53)$ & $(-1.54)$ \\
\hline \multirow[t]{2}{*}{$\operatorname{MAX}(\mathrm{N}) * \mathrm{I}($ port=4) } & -0.048 & -0.066 & -0.081 & -0.093 \\
\hline & $(-4.99)$ & $(-5.46)$ & $(-5.45)$ & $(-5.31)$ \\
\hline \multirow[t]{2}{*}{$\operatorname{MAX}(\mathrm{N}) * \mathrm{I}($ port $=5)$} & -0.071 & -0.094 & -0.113 & -0.131 \\
\hline & $(-6.72)$ & $(-7.10)$ & $(-7.13)$ & $(-6.98)$ \\
\hline \multirow[t]{2}{*}{ Preference Index } & -0.046 & -0.045 & -0.045 & -0.045 \\
\hline & $(-8.12)$ & $(-7.99)$ & $(-7.93)$ & $(-7.88)$ \\
\hline \multirow[t]{2}{*}{ Beta } & -0.017 & -0.013 & -0.011 & -0.009 \\
\hline & $(-1.74)$ & $(-1.67)$ & $(-1.63)$ & $(-1.61)$ \\
\hline \multirow[t]{2}{*}{ Size } & -0.351 & -0.351 & -0.350 & -0.349 \\
\hline & $(-10.08)$ & $(-10.06)$ & $(-10.03)$ & $(-10.00)$ \\
\hline \multirow[t]{2}{*}{ Beme } & 0.832 & 0.831 & 0.830 & 0.830 \\
\hline & $(10.21)$ & (10.19) & (10.19) & (10.18) \\
\hline \multirow[t]{2}{*}{ Mom } & 0.006 & 0.006 & 0.006 & 0.006 \\
\hline & $(4.08)$ & $(4.01)$ & (3.99) & (3.98) \\
\hline \multirow[t]{2}{*}{ Strev } & -0.045 & -0.044 & -0.043 & -0.043 \\
\hline & $(-10.36)$ & $(-9.93)$ & $(-9.63)$ & $(-9.43)$ \\
\hline \multirow[t]{2}{*}{ Illiq } & 0.018 & 0.019 & 0.019 & 0.020 \\
\hline & (3.08) & (3.20) & (3.27) & (3.31) \\
\hline \multirow[t]{2}{*}{ Ivol } & -0.060 & -0.071 & -0.075 & -0.076 \\
\hline & $(-1.29)$ & $(-1.55)$ & $(-1.68)$ & $(-1.71)$ \\
\hline \multirow[t]{2}{*}{ Coskew } & -0.245 & -0.243 & -0.244 & -0.245 \\
\hline & $(-1.20)$ & $(-1.20)$ & $(-1.20)$ & $(-1.21)$ \\
\hline \multirow[t]{2}{*}{ NS } & -0.022 & -0.022 & -0.022 & -0.022 \\
\hline & $(-3.60)$ & $(-3.59)$ & $(-3.57)$ & $(-3.56)$ \\
\hline \multirow[t]{2}{*}{ Assetg } & 0.008 & 0.008 & 0.008 & 0.008 \\
\hline & (2.18) & $(2.17)$ & (2.18) & (2.19) \\
\hline \multirow[t]{2}{*}{ Accruals } & -0.022 & -0.022 & -0.022 & -0.022 \\
\hline & $(-6.25)$ & $(-6.27)$ & $(-6.28)$ & $(-6.29)$ \\
\hline \multirow[t]{2}{*}{ Turnover } & 0.061 & 0.065 & 0.065 & 0.061 \\
\hline & $(0.47)$ & $(0.50)$ & $(0.50)$ & $(0.47)$ \\
\hline
\end{tabular}




\section{Table 11}

Univariate sorting based on the individual investor preference index.

This table reports the value-weighted average monthly returns to portfolios sorted on the individual investor preference index, as well as the results of time-series regressions of high-minus-low portfolio returns on Fama-French-Cahart factors. Newey-West adjusted test statistics are reported in brackets. All portfolios are sorted and rebalanced at month end based on whole sample breaks. Individual preference index is a composite rank based on ten stock characteristics preferred by individual investors and covers January 1976 to December 2014 . The average index level within each portfolio is reported in the last row.

\begin{tabular}{|c|c|c|c|c|c|c|c|c|c|c|c|c|c|c|c|}
\hline Decile & Low & 2 & 3 & 4 & 5 & 6 & 7 & 8 & 9 & High & H-L & $\begin{array}{c}\text { Alpha } \\
\text { 3F }\end{array}$ & $\begin{array}{c}\text { Alpha } \\
\text { 4F }\end{array}$ & $\begin{array}{c}\text { Alpha } \\
5 F\end{array}$ & $\begin{array}{c}\text { Alpha } \\
\text { 6F }\end{array}$ \\
\hline Raw & 1.01 & 1.05 & 1.2 & 0.99 & 0.95 & 0.87 & 0.83 & 0.63 & 0.55 & 0.63 & $\begin{array}{c}-0.37 \\
(-0.94)\end{array}$ & $\begin{array}{c}-0.72 \\
(-1.98)\end{array}$ & $\begin{array}{c}-0.34 \\
(-1.04)\end{array}$ & $\begin{array}{c}-0.32 \\
(-0.94)\end{array}$ & $\begin{array}{c}0.03 \\
(0.10)\end{array}$ \\
\hline Avg Index & 21 & 29 & 35 & 40 & 45 & 51 & 57 & 63 & 69 & 79 & & & & & \\
\hline
\end{tabular}




\title{
Internet Appendix for
}

\section{"Skewness, individual investor preference,}

\author{
and the cross-section of stock returns"
}

\section{Content}

Table A1 Double sorts on the maximum daily returns and the individual preference index, controlling for short-term reversal factor

Table A2 Double sorts on the maximum daily returns and proxies for individual investors' preferences

Table A3 Fama and MacBeth regressions of returns on the interactions of the maximum daily returns and stock characteristics preferred by individual investors and control variables

Table A4 Unconditional MAX spread over different subsamples 


\section{Appendix A1}

Controlling for the short-term reversal factor: Double sorts on the maximum daily returns and individual investor preference index.

This table shows the value-weighted average returns to portfolios double sorted on the maximum daily returns and individual investor preference index and results of time series regressions of high-minus-low portfolios' returns on Fama and French factors [market, size, value, RMW, CMA], Carhart's momentum factor, and short-term reversal factor. Univariate sorting results on MAX is provided in the first row. Newey-West adjusted test statistics are reported in brackets. All portfolios are sorted and rebalanced at month-end based on whole sample breaks. Monthly maximum daily return is based on Bali et.al (2011). The individual preference index is a composite rank based on ten stock characteristics preferred by individual investors and covers January 1976 to December 2014.

\begin{tabular}{|c|c|c|c|c|c|c|c|c|c|c|}
\hline & \multicolumn{5}{|c|}{ Maximum Daily Return Quintiles } & \multicolumn{5}{|c|}{ High MAX - Low MAX } \\
\hline & Low & 2 & 3 & 4 & High & Raw & $\alpha(3 F+S T R E V)$ & $\alpha(4 \mathrm{~F}+\mathrm{STREV})$ & $\alpha(5 F+S T R E V)$ & $\alpha(6 \mathrm{~F}+\mathrm{STREV})$ \\
\hline \multirow[t]{2}{*}{ All } & 1.09 & 1.10 & 1.13 & 0.95 & 0.56 & -0.53 & -0.99 & -0.68 & -0.33 & -0.20 \\
\hline & & & & & & $(-1.74)$ & $(-4.66)$ & $(-2.85)$ & $(-1.79)$ & $(-0.99)$ \\
\hline \multirow[t]{2}{*}{ Low } & 1.07 & 1.03 & 1.15 & 1.11 & 1.16 & 0.07 & 0.05 & 0.19 & 0.54 & 0.59 \\
\hline & & & & & & $(0.24)$ & $(0.18)$ & $(0.71)$ & $(2.09)$ & $(2.18)$ \\
\hline \multirow[t]{2}{*}{2} & 1.23 & 1.26 & 1.01 & 0.98 & 0.94 & -0.30 & -0.33 & -0.26 & 0.06 & 0.06 \\
\hline & & & & & & $(-0.94)$ & $(-1.38)$ & $(-0.96)$ & $(0.25)$ & $(0.24)$ \\
\hline \multirow[t]{2}{*}{3} & 1.23 & 1.43 & 1.08 & 0.88 & 0.24 & -0.98 & -1.15 & -1.05 & -0.56 & -0.55 \\
\hline & & & & & & $(-2.98)$ & $(-4.29)$ & $(-3.69)$ & $(-2.18)$ & $(-2.12)$ \\
\hline \multirow[t]{2}{*}{4} & 1.23 & 1.55 & 1.43 & 0.67 & 0.08 & -1.15 & -1.44 & -1.16 & -0.80 & -0.68 \\
\hline & & & & & & $(-3.57)$ & $(-5.96)$ & $(-4.31)$ & $(-3.45)$ & $(-2.81)$ \\
\hline \multirow[t]{2}{*}{ High } & 1.34 & 1.65 & 1.48 & 1.11 & 0.14 & -1.20 & -1.62 & -1.28 & -1.03 & -0.86 \\
\hline & & & & & & $(-3.01)$ & $(-4.48)$ & $(-3.02)$ & $(-2.91)$ & $(-2.22)$ \\
\hline
\end{tabular}




\section{Appendix A2}

Double sorts on maximum daily returns and proxies for individual investors’ preferences.

This table shows the value-weighted average returns to portfolios double sorted on the maximum daily returns from last month and ten proxies for individual investors' preferences (institutional ownership, small trade fraction, profitability index, size, price level, idiosyncratic volatility, book-to-market ratio, market beta, abnormal trading volume, and dividend payment), and results of time series regressions of high-minus-low portfolios' returns on Fama and French factors [market, size, value, RMW, CMA] and Carhart's momentum factor. Newey-West adjusted test statistics are reported in brackets. Monthly maximum daily return is constructed based on Bali et.al (2011). The ten stock characteristics composite the individual preference index adopted in the main tests. In Panel A, institutional ownership is the sum of percentage holdings by institutional investors with 13F filling and the sample starts in 1980. In Panel B, small trade fraction is the ratio of small trade volume over total trading volume for each stock in each month. Small trades are identified as trades with no more than $\$ 5,000$ in dollar volume, as outlined by Lee and Radhakrishna (2000). The sample starts in 1993 and ends in 2000 due to data availability, the introduction of decimalization and growing use of computerized trading algorithms. In Panel C, profitability index is a composite rank based on five profitability measures (earnings per share, net income, return on equity, return on assets, and gross profit). These measures are taken from quarterly COMPUSTAT, lagged for two months to ensure availability, then matched to stocks at the end of each month and kept constant until new information arrives. In Panel D, size is proxied by market capitalization. In Panel E, price level is the absolute value of price at month-end. In Panel F, idiosyncratic volatility is the variance of the residual obtained by fitting a four-factor model to the previous six months' daily stock returns. In Panel G, book-to-market ratio is constructed quarterly as the book value of equity over market value of equity and. Book value is lagged for two months before sorting. In Panel H, market beta is constructed monthly using daily returns following Scholes (1977) and Dimson (1979) to take into account nonsynchronous trading. In Panel I, abnormal trading volume, the monthly maximum daily trading volume over the average daily trading volume from the past 12 months. In Panel J, the sample is divided into dividend paying stocks and non-dividend paying stocks. At the end of each month, any stock that makes a dividend payment in the previous twelve months is classified as a dividend-paying stock. All portfolios are sorted and rebalanced monthly based on whole sample breaks, expect for size and book-to-market value, which follows NYSE breaks. The sample period is from January 1976 to December 2014, except for institutional ownership and small trade fraction.

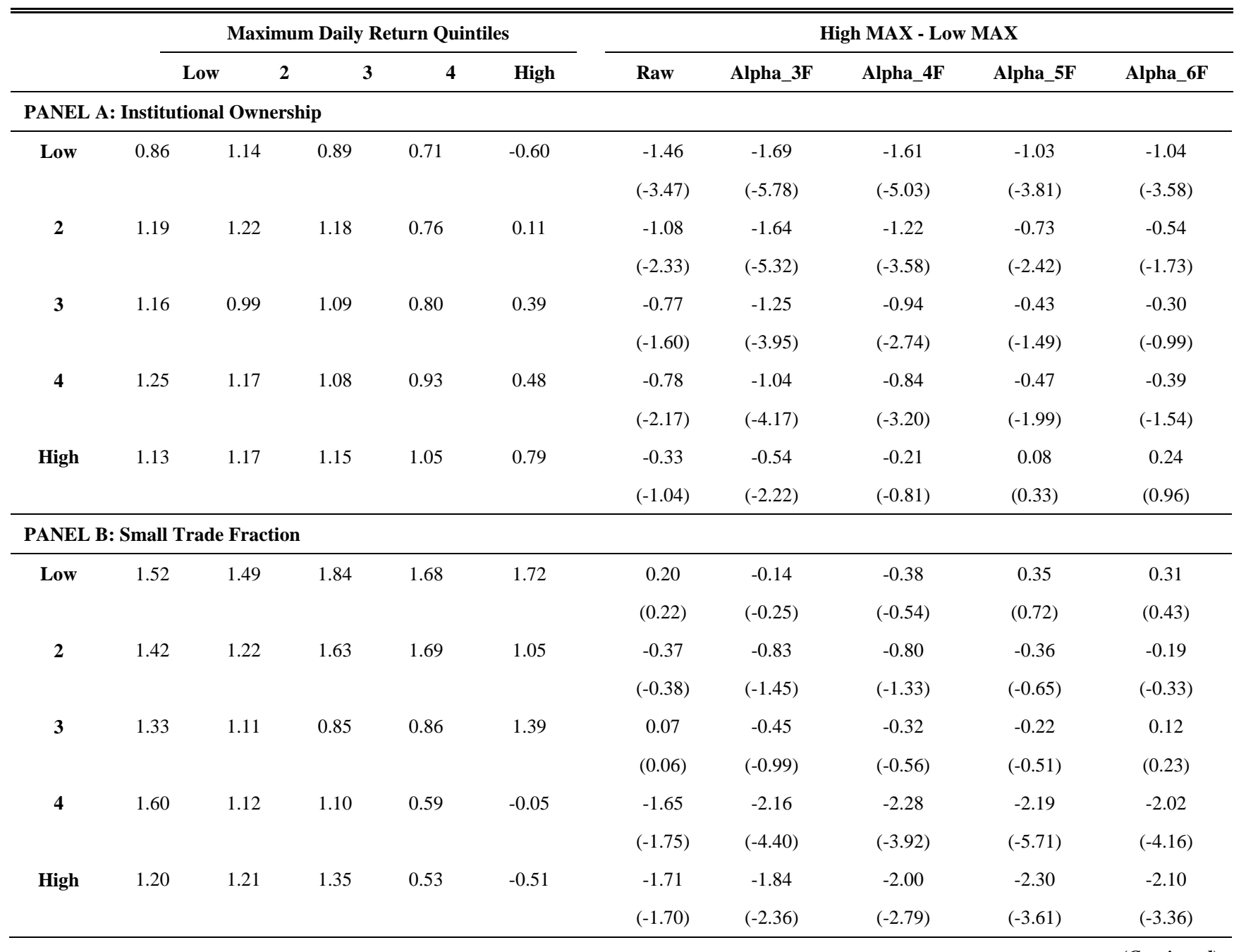




\begin{tabular}{|c|c|c|c|c|c|c|c|c|c|c|}
\hline & \multicolumn{5}{|c|}{ Maximum Daily Return Quintiles } & \multicolumn{5}{|c|}{ High MAX - Low MAX } \\
\hline & Low & 2 & 3 & 4 & High & Raw & Alpha_3F & Alpha_4F & Alpha_5F & Alpha_6F \\
\hline \multicolumn{11}{|c|}{ PANEL C: Profitability } \\
\hline \multirow[t]{2}{*}{ Low } & 0.97 & 1.1 & 0.8 & 0.24 & -0.66 & -1.63 & -2.07 & -1.82 & -1.29 & -1.21 \\
\hline & & & & & & $(-3.85)$ & $(-6.87)$ & $(-5.36)$ & $(-4.74)$ & $(-4.03)$ \\
\hline \multirow[t]{2}{*}{2} & 0.95 & 0.78 & 0.95 & 0.8 & 0.13 & -0.82 & -1.30 & -1.12 & -0.67 & -0.61 \\
\hline & & & & & & $(-2.27)$ & $(-5.01)$ & $(-4.02)$ & $(-2.99)$ & $(-2.54)$ \\
\hline \multirow[t]{2}{*}{3} & 1.08 & 1.06 & 0.99 & 0.96 & 0.79 & -0.30 & -0.70 & -0.59 & -0.36 & -0.32 \\
\hline & & & & & & $(-1.02)$ & $(-3.30)$ & $(-2.58)$ & $(-1.66)$ & $(-1.41)$ \\
\hline \multirow[t]{2}{*}{4} & 1.17 & 0.97 & 1.19 & 0.88 & 0.96 & -0.20 & -0.50 & -0.36 & -0.11 & -0.06 \\
\hline & & & & & & $(-0.73)$ & $(-2.31)$ & $(-1.58)$ & $(-0.49)$ & $(-0.25)$ \\
\hline \multirow[t]{2}{*}{ High } & 1.08 & 1.24 & 1.3 & 1.38 & 1.19 & 0.11 & -0.26 & -0.14 & 0.27 & 0.29 \\
\hline & & & & & & $(0.35)$ & $(-1.02)$ & $(-0.52)$ & (1.09) & (1.13) \\
\hline \multicolumn{11}{|c|}{ PANEL D: Size } \\
\hline \multirow[t]{2}{*}{ Low } & 1.46 & 1.70 & 1.51 & 1.16 & 0.25 & -1.21 & -1.65 & -1.38 & -1.11 & -0.99 \\
\hline & & & & & & $(-3.95)$ & $(-8.41)$ & $(-6.48)$ & $(-5.86)$ & $(-4.86)$ \\
\hline \multirow[t]{2}{*}{2} & 1.63 & 1.56 & 1.39 & 1.06 & 0.65 & -0.99 & -1.32 & -1.09 & -0.73 & -0.63 \\
\hline & & & & & & $(-2.85)$ & $(-5.99)$ & $(-4.39)$ & $(-4.00)$ & $(-3.04)$ \\
\hline \multirow[t]{2}{*}{3} & 1.43 & 1.45 & 1.34 & 0.96 & 0.63 & -0.80 & -1.01 & -0.84 & -0.35 & -0.30 \\
\hline & & & & & & $(-2.39)$ & $(-4.00)$ & $(-3.19)$ & $(-1.57)$ & $(-1.31)$ \\
\hline \multirow[t]{2}{*}{4} & 1.29 & 1.33 & 1.10 & 1.22 & 0.85 & -0.44 & -0.67 & -0.30 & 0.11 & 0.28 \\
\hline & & & & & & $(-1.08)$ & $(-2.23)$ & $(-0.85)$ & $(0.39)$ & $(0.87)$ \\
\hline \multirow[t]{2}{*}{ High } & 0.99 & 1.04 & 1.06 & 1.16 & 0.56 & -0.38 & -0.70 & -0.47 & 0.00 & 0.08 \\
\hline & & & & & & $(-0.86)$ & $(-1.84)$ & $(-1.21)$ & $(0.01)$ & $(0.22)$ \\
\hline \multicolumn{11}{|c|}{ PANEL E: Price Level } \\
\hline \multirow[t]{2}{*}{ Low } & 1.72 & 1.72 & 1.87 & 1.33 & 0.05 & -1.67 & -2.11 & -1.84 & -1.59 & -1.46 \\
\hline & & & & & & $(-3.73)$ & $(-4.98)$ & $(-4.04)$ & $(-3.73)$ & $(-3.28)$ \\
\hline \multirow[t]{2}{*}{2} & 1.27 & 1.74 & 1.59 & 0.82 & -0.03 & -1.30 & -1.76 & -1.55 & -1.26 & -1.17 \\
\hline & & & & & & $(-4.2)$ & $(-8.06)$ & $(-6.47)$ & $(-5.68)$ & $(-4.99)$ \\
\hline \multirow[t]{2}{*}{3} & 1.33 & 1.49 & 1.30 & 1.03 & 0.12 & -1.22 & -1.56 & -1.51 & -1.13 & -1.13 \\
\hline & & & & & & $(-3.77)$ & $(-6.21)$ & $(-5.73)$ & $(-4.92)$ & $(-4.77)$ \\
\hline \multirow[t]{2}{*}{4} & 1.41 & 1.40 & 1.18 & 0.80 & 0.35 & -1.06 & -1.35 & -1.22 & -0.84 & -0.81 \\
\hline & & & & & & $(-3.11)$ & $(-5.87)$ & $(-4.60)$ & $(-4.03)$ & $(-3.41)$ \\
\hline \multirow[t]{2}{*}{ High } & 1.03 & 1.07 & 1.05 & 1.12 & 1.07 & 0.04 & -0.17 & -0.08 & 0.49 & 0.48 \\
\hline & & & & & & $(0.12)$ & $(-0.64)$ & $(-0.29)$ & (1.93) & (1.80) \\
\hline
\end{tabular}




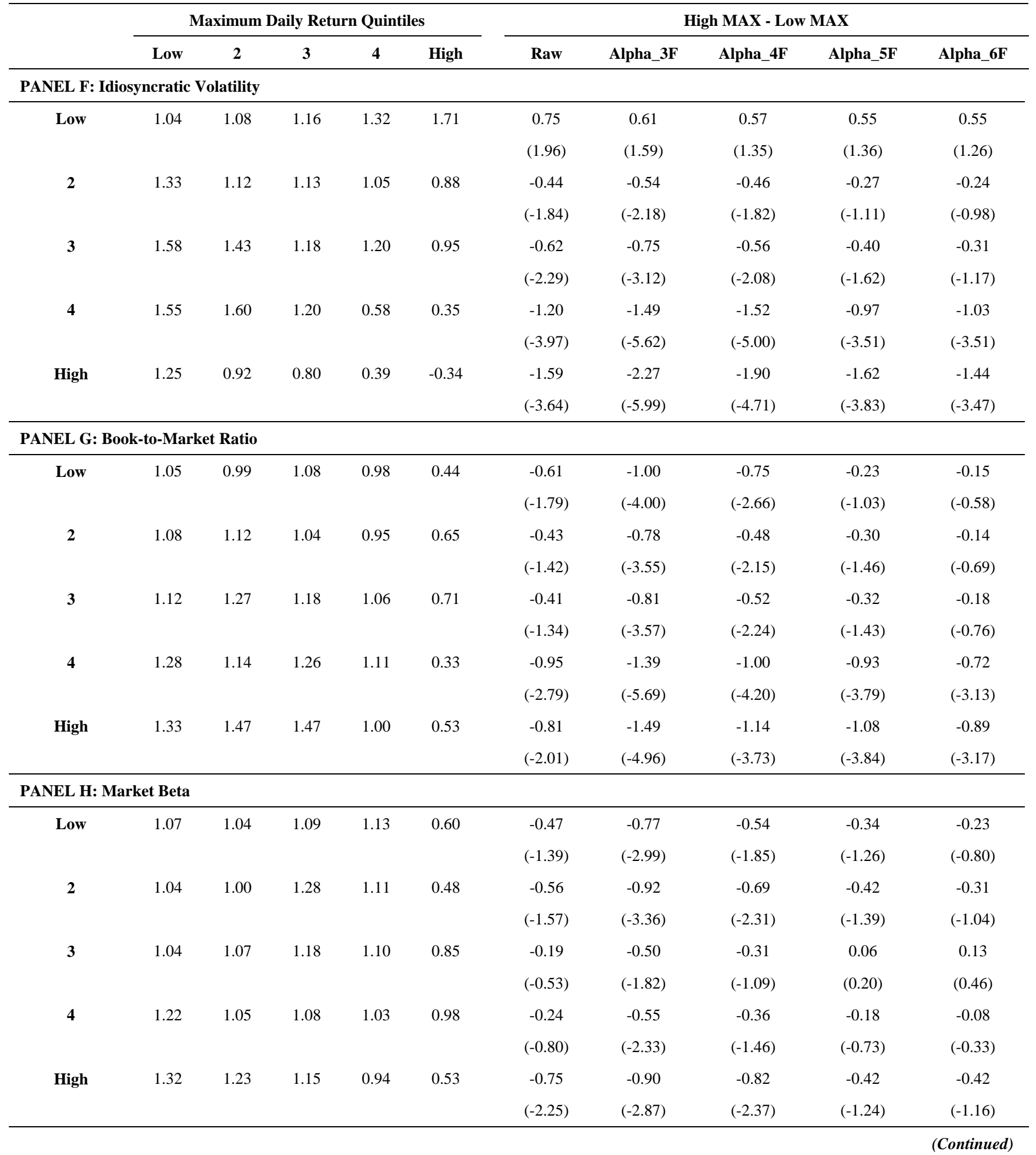




\begin{tabular}{|c|c|c|c|c|c|c|c|c|c|c|}
\hline & \multicolumn{5}{|c|}{ Maximum Daily Return Quintiles } & \multicolumn{5}{|c|}{ High MAX - Low MAX } \\
\hline & Low & 2 & 3 & 4 & High & Raw & Alpha_3F & Alpha_4F & Alpha_5F & Alpha_6F \\
\hline \multicolumn{11}{|c|}{ PANEL I: Abnormal Trading Volume } \\
\hline \multirow[t]{2}{*}{ Low } & 0.98 & 1.04 & 1.00 & 0.68 & 0.00 & -0.97 & -1.58 & -1.02 & -0.82 & -0.52 \\
\hline & & & & & & $(-2.35)$ & $(-5.44)$ & $(-3.34)$ & $(-2.55)$ & $(-1.61)$ \\
\hline \multirow[t]{2}{*}{2} & 1.14 & 1.12 & 1.26 & 0.98 & -0.03 & -1.17 & -1.72 & -1.31 & -1.21 & -0.98 \\
\hline & & & & & & $(-3.16)$ & $(-6.24)$ & $(-4.85)$ & $(-4.2)$ & $(-3.72)$ \\
\hline \multirow[t]{2}{*}{3} & 1.19 & 1.07 & 1.34 & 1.03 & 0.25 & -0.94 & -1.43 & -1.22 & -0.83 & -0.74 \\
\hline & & & & & & $(-2.68)$ & $(-5.53)$ & $(-4.66)$ & $(-3.71)$ & $(-3.22)$ \\
\hline \multirow[t]{2}{*}{4} & 1.20 & 1.36 & 0.95 & 1.19 & 0.85 & -0.35 & -0.73 & -0.56 & -0.09 & -0.04 \\
\hline & & & & & & $(-1.01)$ & $(-2.9)$ & $(-2.04)$ & $(-0.37)$ & $(-0.16)$ \\
\hline \multirow[t]{2}{*}{ High } & 1.32 & 1.30 & 1.25 & 1.14 & 0.91 & -0.40 & -0.74 & -0.61 & -0.28 & -0.23 \\
\hline & & & & & & $(-1.29)$ & $(-3.18)$ & $(-2.23)$ & $(-1.25)$ & $(-0.92)$ \\
\hline \multicolumn{11}{|c|}{ PANEL J: Dividend Payment } \\
\hline \multirow[t]{2}{*}{ No } & 1.29 & 1.38 & 1.31 & 1.21 & 0.44 & -0.85 & -1.25 & -1.04 & -0.60 & -0.53 \\
\hline & & & & & & $(-2.75)$ & $(-5.82)$ & $(-4.13)$ & $(-3.23)$ & $(-2.55)$ \\
\hline \multirow[t]{2}{*}{ Yes } & 1.07 & 1.08 & 1.09 & 0.94 & 0.55 & -0.53 & -0.98 & -0.77 & -0.43 & -0.34 \\
\hline & & & & & & $(-1.70)$ & $(-4.14)$ & $(-3.01)$ & $(-1.91)$ & $(-1.44)$ \\
\hline
\end{tabular}




\section{Appendix A3}

Fama and MacBeth regressions of returns on the interactions of maximum daily returns and stock characteristics and control variables

This table shows average slopes and their Newey-West adjusted t-statistics from monthly cross-section regressions to predict stock returns. We consider the interaction of maximum daily returns and ten proxies for individual investors' preferences: 1) institutional ownership; 2) small trade fraction; 3) profitability, a composite rank of five profit measures (earnings per share, ROE, ROA, net income, and gross profit); 4) size; 5) price level; 6) idiosyncratic volatility, the standard error of four-factor regressions residuals from the past six months' daily returns; 7) book-to-market ratio; 8) market beta; 9) abnormal trading volume; 10) dividend, a dummy variable that equals one if the stock has paid dividend over the past twelve months. I (port=Low) is a dummy variable that equals one if the stock is in the bottom quintile of the proxy, I (port=High) is a dummy variable that equals one if the stock is in the top quintile of the proxy, I (port=2), I (port=3), I (port=4) are defined accordingly. The sample covers from January 1976 to December 2014

\begin{tabular}{|c|c|c|c|c|c|c|c|c|c|c|}
\hline Ind. Var & Inst.Own & Trade $\%$ & Profit & Size & Price & Ivol & BEME & Beta & Volume & Dividend \\
\hline \multirow[t]{2}{*}{ MAX*I(port=1) } & -0.044 & 0.041 & -0.045 & -0.038 & -0.028 & 0.026 & -0.034 & -0.023 & -0.116 & -0.023 \\
\hline & $(-5.62)$ & $(2.10)$ & $(-4.84)$ & $(-3.80)$ & $(-2.66)$ & $(1.95)$ & $(-4.30)$ & $(-2.85)$ & $(-8.37)$ & $(-2.22)$ \\
\hline \multirow[t]{2}{*}{ MAX*I(port=2) } & -0.023 & 0.023 & -0.027 & -0.013 & -0.040 & 0.030 & -0.016 & -0.018 & -0.079 & \\
\hline & $(-2.54)$ & $(1.13)$ & $(-2.36)$ & $(-2.25)$ & $(-5.48)$ & $(4.95)$ & $(-1.98)$ & $(-2.32)$ & $(-8.43)$ & \\
\hline \multirow[t]{2}{*}{ MAX*I(port=3) } & -0.006 & -0.022 & -0.006 & -0.008 & -0.020 & 0.024 & -0.009 & -0.015 & -0.058 & \\
\hline & $(-0.94)$ & $(-1.26)$ & $(-0.73)$ & $(-1.01)$ & $(-1.90)$ & $(3.72)$ & $(-1.54)$ & $(-1.86)$ & $(-7.35)$ & \\
\hline \multirow[t]{2}{*}{ MAX*I(port=4) } & -0.007 & -0.062 & 0.014 & 0.018 & 0.011 & -0.010 & -0.008 & -0.010 & -0.036 & \\
\hline & $(-1.17)$ & $(-5.01)$ & $(2.02)$ & (1.68) & $(1.02)$ & $(-1.86)$ & $(-1.30)$ & $(-1.25)$ & $(-4.60)$ & \\
\hline \multirow[t]{2}{*}{ MAX*I(port=5) } & -0.012 & -0.076 & 0.024 & 0.032 & 0.027 & -0.039 & -0.020 & -0.029 & -0.003 & -0.026 \\
\hline & $(-1.26)$ & $(-7.00)$ & (3.89) & $(2.82)$ & (2.19) & $(-5.23)$ & $(-1.86)$ & $(-3.69)$ & $(-0.46)$ & $(-3.18)$ \\
\hline \multirow[t]{2}{*}{ Preference Proxy } & 0.549 & -0.096 & 0.021 & -0.146 & -0.001 & -0.140 & 0.261 & & 0.009 & 0.090 \\
\hline & (2.35) & $(-0.13)$ & $(7.82)$ & $(-3.76)$ & $(-1.28)$ & $(-2.72)$ & $(4.22)$ & & (2.99) & $(0.84)$ \\
\hline \multirow[t]{2}{*}{ Beta } & 0.017 & 0.071 & -0.001 & -0.004 & 0.011 & -0.006 & 0.013 & 0.014 & 0.020 & 0.003 \\
\hline & $(0.47)$ & $(1.25)$ & $(-0.03)$ & $(-0.12)$ & $(0.37)$ & $(-0.17)$ & $(0.43)$ & $(0.30)$ & $(0.64)$ & $(0.09)$ \\
\hline \multirow[t]{2}{*}{ Size } & -0.197 & -0.132 & -0.179 & & -0.184 & -0.143 & -0.135 & -0.127 & -0.088 & -0.160 \\
\hline & $(-5.11)$ & $(-1.87)$ & $(-5.56)$ & & $(-5.62)$ & $(-4.40)$ & $(-4.52)$ & $(-4.06)$ & $(-2.85)$ & $(-5.07)$ \\
\hline \multirow[t]{2}{*}{ Beme } & 0.474 & 0.759 & 0.581 & 0.505 & 0.480 & 0.478 & & 0.607 & 0.578 & 0.470 \\
\hline & (6.09) & (3.33) & (7.87) & $(7.02)$ & $(6.62)$ & (6.69) & & $(8.06)$ & (7.89) & (6.65) \\
\hline \multirow[t]{2}{*}{ Mom } & 0.007 & 0.010 & 0.004 & 0.007 & 0.007 & 0.007 & 0.007 & 0.009 & 0.008 & 0.007 \\
\hline & $(4.07)$ & $(6.45)$ & $(2.56)$ & (4.29) & $(4.27)$ & $(4.37)$ & $(4.56)$ & (5.52) & (4.99) & $(4.28)$ \\
\hline \multirow[t]{2}{*}{ Strev } & -0.039 & -0.032 & -0.052 & -0.047 & -0.047 & -0.047 & -0.046 & -0.042 & -0.045 & -0.046 \\
\hline & $(-8.72)$ & $(-4.71)$ & $(-11.74)$ & $(-10.74)$ & $(-10.90)$ & $(-10.79)$ & $(-11.32)$ & $(-9.80)$ & $(-10.67)$ & $(-10.57)$ \\
\hline \multirow[t]{2}{*}{ Illiq } & 0.028 & 0.064 & 0.019 & 0.024 & 0.020 & 0.022 & 0.018 & 0.020 & 0.018 & 0.021 \\
\hline & $(4.42)$ & (3.74) & (3.63) & $(4.43)$ & (3.81) & $(4.14)$ & $(4.02)$ & (3.32) & (2.84) & (3.90) \\
\hline \multirow[t]{2}{*}{ Ivol } & -0.267 & -0.036 & -0.147 & -0.212 & -0.223 & & -0.240 & -0.184 & -0.113 & -0.242 \\
\hline & $(-4.92)$ & $(-0.39)$ & $(-3.07)$ & $(-4.10)$ & $(-4.61)$ & & $(-4.73)$ & $(-3.25)$ & $(-2.01)$ & $(-4.99)$ \\
\hline \multirow[t]{2}{*}{ Coskew } & -0.135 & -0.582 & -0.167 & -0.151 & -0.200 & -0.140 & -0.082 & -0.201 & -0.312 & -0.166 \\
\hline & $(-0.61)$ & $(-1.09)$ & $(-0.82)$ & $(-0.71)$ & $(-0.95)$ & $(-0.67)$ & $(-0.41)$ & $(-0.94)$ & $(-1.47)$ & $(-0.80)$ \\
\hline \multirow[t]{2}{*}{ NS } & -0.027 & -0.041 & -0.011 & -0.028 & -0.028 & -0.027 & -0.026 & -0.028 & -0.026 & -0.028 \\
\hline & $(-4.88)$ & $(-3.99)$ & $(-1.89)$ & $(-4.43)$ & $(-4.37)$ & $(-4.37)$ & $(-5.28)$ & $(-4.53)$ & $(-4.14)$ & $(-4.43)$ \\
\hline \multirow[t]{2}{*}{ Assetg } & 0.008 & 0.004 & 0.004 & 0.010 & 0.010 & 0.010 & 0.008 & 0.011 & 0.011 & 0.010 \\
\hline & (1.79) & $(1.25)$ & (1.06) & (2.13) & $(2.26)$ & (2.09) & (1.68) & $(2.23)$ & $(2.21)$ & (2.08) \\
\hline \multirow[t]{2}{*}{ Accruals } & -0.017 & -0.029 & -0.029 & -0.017 & -0.017 & -0.017 & -0.016 & -0.019 & -0.018 & -0.017 \\
\hline & $(-4.41)$ & $(-4.55)$ & $(-8.41)$ & $(-4.79)$ & $(-4.90)$ & $(-4.82)$ & $(-4.32)$ & $(-5.30)$ & $(-5.04)$ & $(-4.83)$ \\
\hline \multirow[t]{2}{*}{ Turnover } & 0.340 & 0.111 & 0.358 & 0.361 & 0.410 & 0.373 & 0.457 & 0.295 & -0.038 & 0.445 \\
\hline & (2.67) & $(0.51)$ & (2.72) & (2.68) & (2.75) & (2.89) & (3.62) & (2.24) & $(-0.26)$ & (3.36) \\
\hline
\end{tabular}




\section{Appendix A4}

Unconditional MAX spread over different subsamples

For each month, all stocks in the sample are ranked into decile portfolios based on their maximum daily returns from the previous month. MAX spread is the time-series average returns of buying stocks in the top decile and selling stocks in the bottom decile. Portfolios are value-weighted and rebalanced every month. Each subsequent row in the table represents a monotonically decreasing sample of stocks obtained by sequentially excluding stocks in the lowest 5\% individual preference index group. Individual preference index is a composite rank based on ten stock characteristics preferred by individual investors. Newey-West t-statistics are provided in parentheses. The first three columns report four-factor, five-factor, and six-factor adjusted MAX profits. The fourth column shows the market capitalization of the given subsample as a percentage of the whole sample. The last column provides the average number of firms per month in each subsample. Subsamples on individual preference index cover from January 1976 to December 2014.

\begin{tabular}{|c|c|c|c|c|c|}
\hline Stock Samples & 4F Alpha & 5F Alpha & 6F Alpha & Percent of Total Market Cap & Number of Firms \\
\hline \multirow[t]{2}{*}{ All Firms } & -1.05 & -0.53 & -0.42 & 100.00 & 5255 \\
\hline & $(-3.73)$ & $(-2.39)$ & $(-1.52)$ & & \\
\hline \multirow[t]{2}{*}{ Exclude Btm 5\% } & -1.20 & -0.65 & -0.55 & 69.29 & 4995 \\
\hline & $(-4.12)$ & $(-2.65)$ & $(-2.09)$ & & \\
\hline \multirow[t]{2}{*}{ Exclude Btm 10\% } & -1.30 & -0.72 & -0.63 & 49.63 & 4733 \\
\hline & $(-4.33)$ & $(-2.83)$ & $(-2.31)$ & & \\
\hline \multirow[t]{2}{*}{ Exclude Btm 15\% } & -1.55 & -1.00 & -0.92 & 36.20 & 4471 \\
\hline & $(-5.34)$ & $(-4.35)$ & $(-3.7)$ & & \\
\hline \multirow[t]{2}{*}{ Exclude Btm 20\% } & -1.48 & -0.91 & -0.83 & 26.41 & 4208 \\
\hline & $(-5.08)$ & $(-3.82)$ & $(-3.2)$ & & \\
\hline \multirow[t]{2}{*}{ Exclude Btm 25\% } & -1.63 & -1.08 & -1.02 & 19.42 & 3946 \\
\hline & $(-5.4)$ & $(-4.43)$ & $(-3.91)$ & & \\
\hline \multirow[t]{2}{*}{ Exclude Btm 30\% } & -1.67 & -1.14 & -1.06 & 14.27 & 3683 \\
\hline & $(-5.31)$ & $(-4.33)$ & $(-3.88)$ & & \\
\hline \multirow[t]{2}{*}{ Exclude Btm 35\% } & -1.37 & -0.90 & -0.79 & 10.57 & 3420 \\
\hline & $(-4.35)$ & $(-3.35)$ & $(-2.78)$ & & \\
\hline \multirow[t]{2}{*}{ Exclude Btm 40\% } & -1.40 & -0.97 & -0.85 & 7.88 & 3157 \\
\hline & $(-4.23)$ & $(-3.46)$ & $(-2.87)$ & & \\
\hline \multirow[t]{2}{*}{ Exclude Btm 45\% } & -1.62 & -1.20 & -1.07 & 5.92 & 2894 \\
\hline & $(-5.00)$ & $(-4.36)$ & $(-3.69)$ & & \\
\hline \multirow[t]{2}{*}{ Exclude Btm 50\% } & -1.77 & -1.39 & -1.28 & 4.39 & 2631 \\
\hline & $(-5.97)$ & $(-5.71)$ & $(-4.87)$ & & \\
\hline \multirow[t]{2}{*}{ Exclude Btm 55\% } & -1.95 & -1.59 & -1.49 & 3.22 & 2369 \\
\hline & $(-6.34)$ & $(-5.75)$ & $(-5.03)$ & & \\
\hline \multirow[t]{2}{*}{ Exclude Btm 60\% } & -2.07 & -1.69 & -1.57 & 2.34 & 2106 \\
\hline & $(-6.01)$ & $(-5.50)$ & $(-4.74)$ & & \\
\hline \multirow[t]{2}{*}{ Exclude Btm 65\% } & -2.48 & -2.15 & -2.08 & 1.66 & 1843 \\
\hline & $(-7.34)$ & $(-7.65)$ & $(-6.82)$ & & \\
\hline \multirow[t]{2}{*}{ Exclude Btm 70\% } & -2.75 & -2.38 & -2.34 & 1.16 & 1580 \\
\hline & $(-7.87)$ & $(-7.95)$ & $(-7.37)$ & & \\
\hline \multirow[t]{2}{*}{ Exclude Btm 75\% } & -2.68 & -2.32 & -2.24 & 0.78 & 1317 \\
\hline & $(-7.2)$ & $(-7.25)$ & $(-6.45)$ & & \\
\hline \multirow[t]{2}{*}{ Exclude Btm 80\% } & -2.66 & -2.33 & -2.26 & 0.51 & 1054 \\
\hline & $(-6.96)$ & $(-7.21)$ & $(-6.49)$ & & \\
\hline
\end{tabular}




\begin{tabular}{cccccc} 
(Continued) & & & & \\
\hline Stock Samples & 4F Alpha & 5F Alpha & 6F Alpha & Percent of Total Market Cap & Number of Firms \\
\hline Exclude Btm 85\% & -3.01 & -2.58 & -2.59 & 0.31 & 791 \\
& $(-7.43)$ & $(-6.98)$ & $(-6.83)$ & & 0.16 \\
Exclude Btm 90\% & -3.03 & -2.55 & -2.61 & & 528 \\
& $(-6.99)$ & $(-5.98)$ & $(-5.92)$ & 0.05 & 264 \\
Exclude Btm 95\% & -2.69 & -2.40 & -2.59 & & $(-4.24)$ \\
& $(-4.41)$ & $(-3.92)$ & & & \\
\hline \hline
\end{tabular}

